\title{
The Kvabebi Canidae record revisited (late Pliocene, Sighnaghi, eastern Georgia)
}

\author{
Lorenzo Rook, ${ }^{1}$ Saverio Bartolini Lucenti, ${ }^{1,2}$ Maia Bukhsianidze, ${ }^{3}$ and David Lordkipanidze ${ }^{3}$ \\ ${ }^{1}$ Dipartimento di Scienze della Terra, Università di Firenze, Via G. La Pira 4, 50121 Firenze, Italy 〈lorenzo.rook@unifi.it〉 \\ ${ }^{2}$ Dottorato di Ricerca in Scienze della Terra, Università di Pisa, Via S. Maria 53, 56126 Pisa, Italy 〈saverio.bartolini@dst.unipi.it〉 \\ ${ }^{3}$ Georgian National Museum, 3, Rustaveli ave., Tbilisi-0105, Georgia 〈maiabukh@gmail.com〉; 〈dlordkipanidze@museum.ge〉
}

\begin{abstract}
Unlike the Asian and North American Pliocene record, fossil occurrences of Canidae in Europe (and Africa) are uncommon and fragmentary. The revision of canid material from the late Pliocene site of Kvabebi (eastern Georgia) revealed the contemporaneous occurrence of three different taxa: (1) Nyctereutes megamastoides (a derived species of the Eurasian Pliocene raccoon dog-like canids); (2) Vulpes cf. V. alopecoides (representing the first occurrence of a member of the vulpine taxon V. alopecoides, a species that was the most widespread fox in the early Pleistocene in western Europe); and (3) Eucyon sp. The latter occurrence at Kvabebi completes our knowledge of the late Pliocene evolutionary history of the latest representatives of the genus in Western Europe and Central Asia. Our revision of Kvabebi canids registers a previously undocumented case of established niche partitioning among early Pliocene sympatric Canidae.
\end{abstract}

\section{Introduction}

The European record of Pliocene canids is relatively scanty and consists mainly of a few specimens in isolated occurrences. The most common taxon recovered from early Pliocene sites is the genus Nyctereutes Temminck, 1838, whereas the genus Eucyon Tedford and Qiu, 1996 is more elusive during this period. The genus Vulpes Frisch, 1775, which has been present in North America and Africa since the late Miocene, is documented in Eurasia only from the early Pliocene (Wang and Tedford, 2008).

Vekua (1972) described the fossil assemblage of Kvabebi, a late Pliocene site (MN16a in the European Land Mammal biochronology). Mein (1975a, b) and Agustí et al. (2009) reported the co-occurrence of Nyctereutes megamastoides (Pomel, 1842) and Canis sp. in Eastern Georgia. Agustí et al. (2009) provided a general revision of the Kvabebi fauna and its chronological position. The authors, by providing a magnetostratigraphic calibration of the Kvabebi succession to the late Pliocene (chron 2An.1r), reviewed the faunal list ascribing the canid record to the genera Nyctereutes and Eucyon. In the framework of a joint collaborative project between the University of Florence and the Georgian National Museum (GNM), the Kvabebi Canidae sample has been revised to examine its role in determining the evolutionary history of the Plio-Pleistocene canid guild of the Old World. This revision of all the available material from Kvabebi housed in the GNM paleontological collections allowed us to identify the co-occurrence of three different canids in the same fossil assemblage: Nyctereutes, Eucyon, and Vulpes. This association is remarkable for its diversity and because it includes the first occurrence of a Vulpes alopecoides-like fox in the European fossil record.
Geological and chronological context of the Kvabebi site.Kvabebi is located south of Magaro village, in the area of the Sighnaghi region of eastern Georgia that surrounds Kvabebi Mountain, on the southern edge of the Iori Plateau. The Kvabebi section sits in the sedimentary infill of the Kura Basin. The latter, since the late Neogene, has been bordered by the Greater Caucasus to northeast and by the Lesser Caucasus and the Talysh ranges to the southwest (Agustí et al., 2009, fig. 1), and it formed as a northward inland ingression of the Caspian (Popov et al., 2006). The Kvabebi section, which is in the middle part of the Akchagylian stage of the Caspian Paratethys (Vekua, 1972), is $\sim 170 \mathrm{~m}$ thick and displays a general regressive trend. The lower $110 \mathrm{~m}$ of the section is built up of a succession of brownish and bluish laminated mudstones. The brownish sediments are of fluvio-lacustrine origin, whereas the bluish color testifies to transgressive (marine) events characterized by a Pliocene (Akchagylian) mollusk fauna (Djikia, 1968). The upper part of the section (from $110 \mathrm{~m}$ to the top) is formed by a succession of alluvial reddish-brown sediments with no marine fauna. The section is characterised by the occurrence of several sandstone layers, including the one that yielded the Kvabebi fossil vertebrate assemblage (at meter 40), which is the result of accumulation due to tractive processes in a fluvial-influenced environment (Agustí et al., 2009).

Recent re-prospecting and re-excavating conducted at Kvabebi allowed a re-evaluation of the geochronological setting of the section and a revision of the vertebrate fauna assemblage (Agustí et al., 2009). A magnetostratigraphic study allowed placement of the fossiliferous level within the polarity reversals chron 2An.1r, with an age of ca. 3.07 Ma for the Kvabebi site (Agustí et al., 2009). The updated revised list of the Kvabebi 
vertebrate fauna (Vekua, 1972; Hemmer et al., 2004; Agustí et al., 2009; this paper) is as follows:

Reptilia

Testudo cernovi transcaucasica Chkhikvadze, 1979

Aves

Ioriotis gabuniae Burchak-Abramovich and Vekua, 1971; Struthio transcaucasicus Burchak-Abramovich and Vekua, 1971 Mammalia

Rodentia: Hystrix cf. H. primigenia Wagner, 1848

Carnivora: Nyctereutes megamastoides (Pomel, 1842); Eucyon sp., Vulpes cf. V. alopecoides (Del Campana, 1913); Ursus minimus Devèze and Bouillet, 1827; Lynx issiodorensis (Croizet and Jobert, 1828); Homotherium davitashvili Vekua, 1972; Puma pardoides Owen, 1846; Dinofelis cristata (Falconer and Cautley, 1836); Chasmaportetes lunensis (Del Campana, 1914); Perinium kvabebicus (Bendukize and Vekua, 2012)

Arctiodactyla: Propotamochoerus provincialis (Gervais, 1859); Eucladoceros sp.; ?Pseudalces sp.; Procapreolus sp.; Ioribos aceros Vekua, 1972; Protoryx heinrichi Major, 1891; Oryx (Aegoryx) sp.; Parastrepsiceros sokolovi Vekua, 1968; Eosyncerus ivericus Vekua, 1972; Gazella postmitilinii Vekua, 1972

Perissodactyla: Hipparion rocinantis Hernández Pacheco, 1921; Stephanorhinus megarhinus (de Christol, 1834)

Hyracoidea: Kvabebihyrax kachethicus Gabunia and Vekua, 1966

Probiscidea: Anancus arvernensis (Croizet and Jobert, 1828)

\section{Materials and methods}

Studied specimens and comparative sample.-The present study is based on comparative morphological analyses of the Canidae from Kvabebi. The examined and described fossils are housed at the GNM (see abbreviations below). We studied the collections of the IGF as comparative fossil material, and reviewed the relevant literature on Plio-Pleistocene canids (Del Campana, 1913; Thenius, 1954; Qiu and Tedford, 1990; Teford and Qiu, 1991, 1996; Koufos, 1997; Rook, 2009; Petrucci et al., 2013; Koufos, 2014). Extant specimens from the MZUF, MNHN, and GNM were also used for morphological and morphometric comparisons.

The fossil comparative sample includes specimens of Nyctereutes donnezani (Depéret, 1890) from La Gloria and Layna; Nyctereutes megamastoides (Pomel, 1842) from the Lower Valdarno Basin, Villaroya, Dafnero 1; Nyctereutes vulpinus Monguillon et al., 2004 from St. Vallier; Nyctereutes sinensis (Schlosser, 1903) and Nyctereutes tingi Tedford and Qiu, 1991 from the Yushe Basin; Eucyon monticenensis (Rook, 1992) from the Cava Monticino and Venta del Moro; Eucyon adoxus (Martin, 1973) from Perpignan; Eucyon marinae Spassov and Rook, 2006 from Muhor-Erig; Eucyon davisi (Merriam, 1911) from North America and the Yushe Basin; Eucyon zhoui from the Yushe Basin; Eucyon odessanus (Odintzov, 1967) from Megalo Emvolon, Alatini and the Odessa Catacombs; Eucyon minor (Teilhard de Chardin and Piveteau, 1930) from Nihewan and Shamar; Vulpes alopecoides (Major, 1875) from the Upper Valdarno Basin, Pirro Nord and Dafnero-1; Vulpes praeglacialis (Kormos, 1932) and Vulpes praecorsac Kormos, 1932 from Spain, Hungary, and Ukraine.
The extant comparative sample includes specimens of Nyctereutes procyonoides (Gray, 1834), Vulpes vulpes (Linnaeus, 1758), and Vulpes lagopus (Linnaeus, 1758), which are housed in the MZUF, MNHN, and GNM.

Measurements and statistical analyses.-Cranio-dental and postcranial measurements were taken with a digital calliper to the nearest $0.1 \mathrm{~mm}$ following von den Driesch (1976), with a few modifications. We used linear measurements and the ratio of the width/length of $\mathrm{m} 1$ to create scatter plots to test the affinity of the specimens of Vulpes and Eucyon from Kvabebi within the variability of Plio-Pleistocene species of these two genera. For Vulpes, we decided to include the extant species $V$. vulpes and $V$. lagopus for the widespread distribution of the former and size affinity of the latter to fossil species. Fossil species taken into consideration are European Plio-Pleistocene ones (e.g., $V$. praecorsac, V. praeglacialis, and V. alopecoides). We decided to keep convex hulls only for fossil species to identify their variability range compared to extant ones, which are considerably more variable. In the Eucyon scatter plot, we included six species of the Eurasian Pliocene Eucyon (E. marinae, E. adoxus, E. minor, E. davisi, E. zhoui, and E. odessanus) and preferred to leave only the convex hull of $E$. odessanus for its great variability.

In these analyses, we used PAST software ver. 3.08 (Hammer et al., 2001; Hammer, 2016). We further clarified the specific attribution of the material of Nyctereutes by comparing the material from Kvabebi with that of other Eurasian Villafranchian and extant species of the genus by means of two log-ratio diagrams (Simpson, 1941; Simpson et al., 1960). These graphs calculate the difference between the log-transformed mean value of each single variable for each species and a selected species that is chosen as the comparative baseline. The dental variables selected are P2-P3 L, P4-M2 L, and W for the upper teeth, and p2-p3 L, p4-m2 L, and W. We chose the extant $N$. procyonoides as a reference baseline and plotted the following fossil species: $N$. megamastoides from European sites; $N$. tingi and $N$. sinensis from China; and Nyctereutes from Kvabebi.

Repositories and institutional abbreviations.-IGF, Museum of Natural History, Geological and Paleontological section, University of Florence (Italy); K, Kvabebi site; MG, S. Janashia Museum of Georgia, part of the Georgian National Museum (Tbilisi, Georgia); MNHN, Museum National d'Histoire Naturelle, Paris; MZUF, Museum of Natural History, "La Specola" Zoology section, University of Florence (Italy).

\section{Systematic paleontology}

Anatomical abbreviations.-Postcranial: GL, general length; $\mathrm{Bd}$, breadth of the distal epiphysis; $\mathrm{Bp}$, breadth of the proximal epiphysis; BPC, greatest breadth across the coronoid process; DC, depth of the caput femoris; Dd, depth of the distal epiphysis; Dp, depth of the proximal epiphysis; DPA, depth across the processus anconaeus

Order Carnivora Bowdich, 1821

Suborder Caniformia Kretzoi, 1943

Family Canidae Fischer von Waldheim, 1817

Subfamily Caninae Fischer von Waldheim, 1817 
Tribe Vulpini Hemprich and Ehrenberg, 1832

Genus Nyctereutes Temminck, 1838

Nyctereutes megamastoides (Pomel, 1842) Figures 1, 2

1972 Nyctereutes megamastoides Vekua, p. 41, pl. 2, figs. 1, 2, pl. 3, figs.1, 6 .

2009 Nyctereutes megamastoides Agustí et al., p. 3277.

Holotype.-The holotype of Nyctereutes megamastoides comes from Perrier-Etouaires (early Pleistocene), France.
Materials.-MG 29-2013/455 (K234) juvenile cranium with left dP4 and M1 and right P4-M2; MG 29-2013/456 (K217) cranium; MG 29-2013/457 (K220) cranium with left C1-M2 and right P1-M2; MG 29-2013/567 (K4173) neurocranium; MG 29-2013/568 (K215) cranium; GNM 29-2013/573 (K233) skull; MG 29-2013/581 cranium; GM 29-2013/610 (K227) left C1; MG 29-2013/609 (K237) left M1; MG 29-2013/588 (K221) left hemimandible with i2, c1-p1, m1-m3; MG 29-2013/589 (K224) right hemimandible with p4-m2; MG 29-2013/590 (K235) right hemimandible with $\mathrm{dm} 1$ and germinal $\mathrm{m} 1$; MG 29-2013/591 (K214) right hemimandible with m1; MG 29-2013/592 (K4177) right hemimandible with p4-m1;
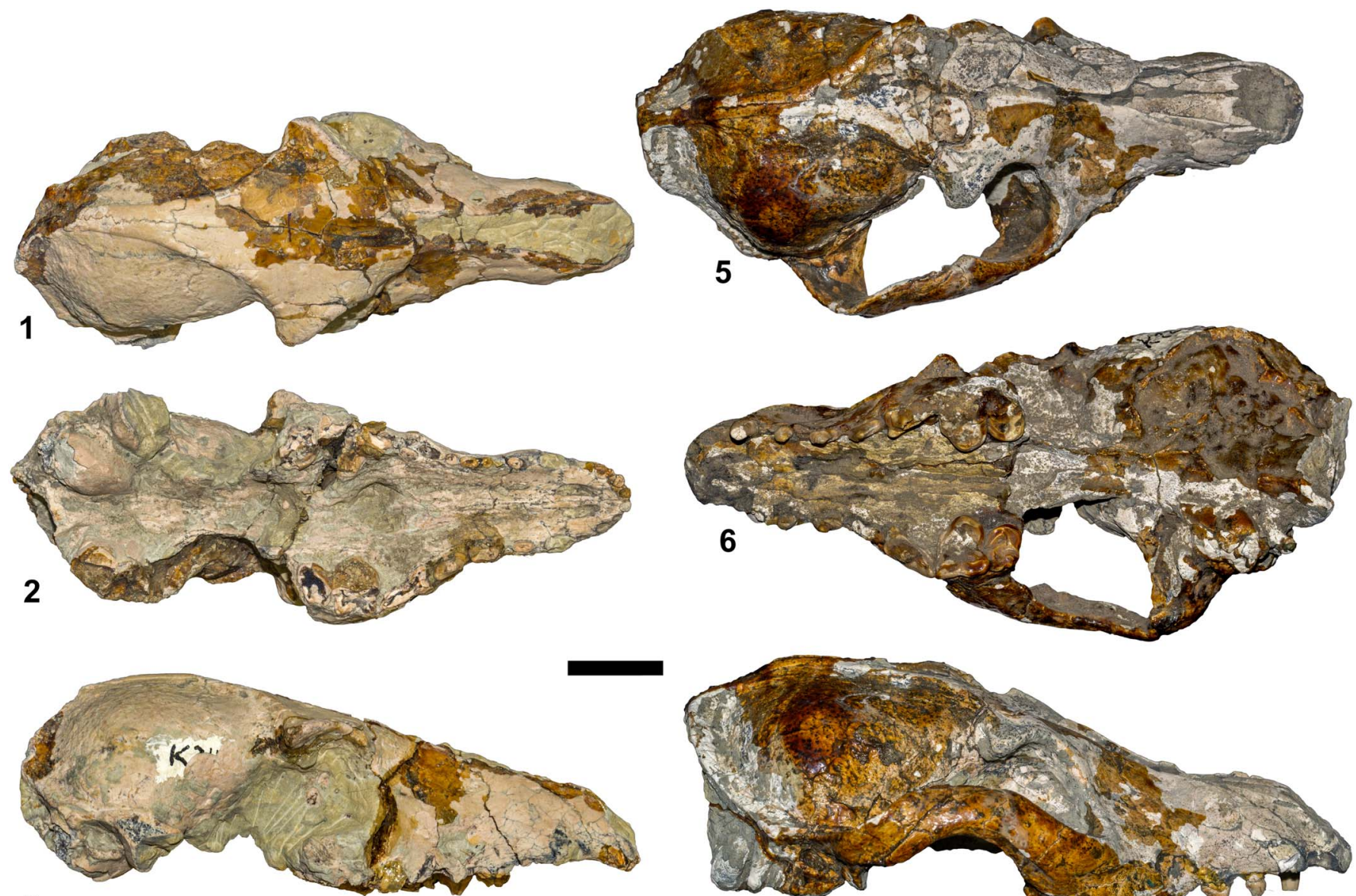

3
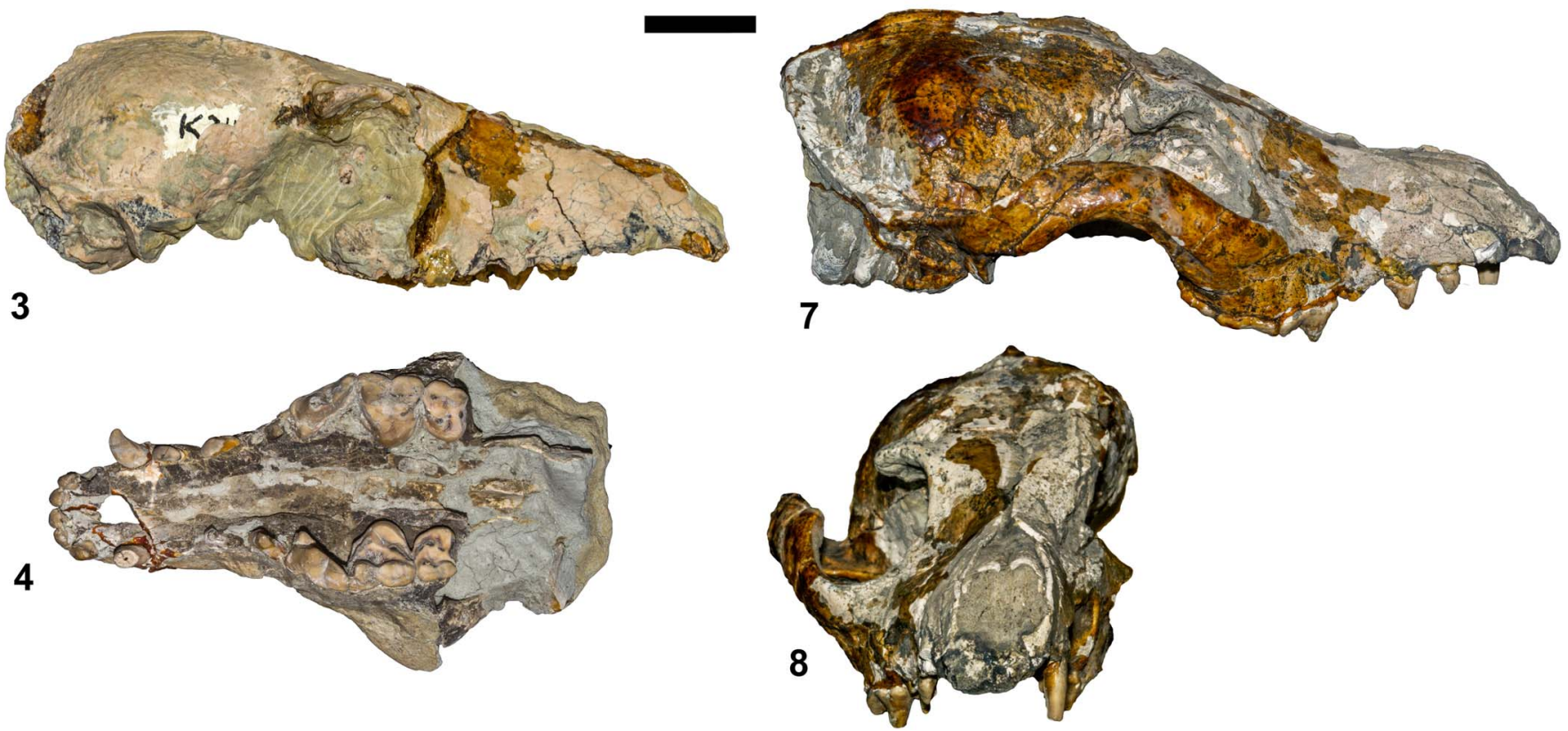

Figure 1. Nyctereutes megamastoides (Pomel, 1842) from Kvabebi. MG 29-2013/581 (K219), cranium, in dorsal (1), ventral (2) and right lateral (3) views; MG 29-2013/456 (K217), cranial fragment, in occlusal view (4); MG 29-2013/457 (K220), cranium, dorsal (5), ventral (6), right lateral (7) and rostral (8) views. Scale bar $=2 \mathrm{~cm}$. 
MG 29-2013/606 right hemimandible with c1; MG 29-2013/ 820 left hemimandible with p2-m3; MG 29-2013/612 (K236) c/C; MG 29-2013/613 incisors, c1 and p1; MG 29-2013/605 (K256) left p4; MG 29-2013/611 right m2; MG 29-2013/593 vertebral fragments (K502 and K504); MG 29-2013/458 left humerus (K251), ulna, and radius (K250); MG 29-2013/594 left humerus (K241), ulna (K239), radius (K245), metacarpals II-V, and I phalanx; MG 29-2013/596 (K232) left radius; MG 29-2013/602 (K503) right pelvis; MG 29-2013/598 (K501) left femur; MG 29-2013/600 (K226) right femur; MG 29-2013/599 (K820) right tibia; MG 29-2013/601 left calcaneum; MG 29-2013/597 (K253) metapodial fragments and phalanges; MG 29-2013/460 (K254) left phalanges.

Description.-The cranium is elongated rostro-caudally, with a long muzzle and long nasals, which end beyond the maxillofrontal suture. In lateral view, the cranial profile is rather straight on the nasals and frontals aspects and becomes arched only in the caudal portion of the braincase (e.g., Fig. 1). The frontals show a depression on the midline of the cranium at the level of the postorbital processes. These are expanded laterally and are well developed. The postorbital constriction is short and marked, so that the frontal sinuses are slightly developed and have a flat external surface. The braincase is rather inflated and globular in shape. The sagittal crest is poorly developed, with some specimens (e.g., K219) showing long parasagittal crests that fuse distally from the fronto-parietal suture and others (e.g., K215) having parasagittal crests that fuse at the level of the fronto-parietal suture. In caudal view, the supraoccipital shield is "bell"-shaped, with prominent borders and a marked knoblike expansion at level of the mastoid process. In lateral view, the inion does not overhang the condyles. The tympanic bullae are fairly inflated. The paraoccipital processes are not fused with the bulla and are posteriorly directed.

Unfortunately, the only juvenile cranium (MG 29-2013/ 455 [K234]) is too poorly preserved to assess correctly its morphological features. It appears to be low in dorso-ventral height, in lateral view. In dorsal view, the braincase is inflated and the postorbital constriction seems rather marked.

The incisors possess a main cusp with two small accessory cuspids on both sides of the main cusp. I3 is slightly larger compared to I1-I2, but still maintains an incisor morphology (not canine form) and does not possess the basal cingulum. $\mathrm{C} 1$ is very thin and its crown is not very high. Short diastemata are visible between upper premolars. The premolars do not show distal accessory cuspids. The $\mathrm{P} 3$ possesses a tiny cuspid on the distal cingulum. The $\mathrm{P} 4$ is rather slender and elongated mesiodistally. The protocone is small, pointy, and anteriorly positioned compared to the mesial margin of the tooth. Some specimens (e.g., K217) seem to show a parastyle in the mesiolingual portion of the $\mathrm{P} 4$. The paracone is high and the metastylar blade is sharp and short. There is a strong lingual cingulum. The M1 is subquadrate in shape. It possesses an equally developed paracone and metacone, bounded buccally by a strong cingulum. There is a prominent parastyle. The M1 shows a large trigon basin, a prominent protocone, a large protoconule and a low, but well-developed, metaconule. Lingually, there is a cingular hypocone. On the mesial side, there is a strong cingulum that forms a bulging of enamel in the shape of a small cuspid. The M2 is large mesio-distally and possesses an equal-sized paracone and metacone, a protocone, a protoconule, and a small metaconule. There is a lingual cingulum. The mandible is long and rather shallow, with a straight ventral margin. In the angular region, the subangular lobe is well developed and high-angled, in lateral view. The angular process is large and stout. The masseteric fossa is deep.

MG 29-2013/590 (K235) possesses dm1 with a broken paraconid and a pointy and high protoconid; its talonid basin is wide and bounded by an entoconid, hypoconid, and a prominent distal accessory cuspulid. Of the lower premolars, only p4 possesses a distal accessory cuspulid, although there is a cuspulid-like distal cingulid on $\mathrm{p} 3$ and $\mathrm{p} 4$. The $\mathrm{p} 4$ also possesses a slightly visible mesial cingulid. The $\mathrm{m} 1$ paraconid is short, lower than the $\mathrm{p} 4$ protoconid. The protoconid is high, whereas the large metaconid is individualized from the protoconid, slight lingually, and distally positioned compared to the distal margin of the protoconid. In the talonid, the hypoconid is larger based compared to the entoconid, but not sensibly higher. In K4177, there are accessory cuspulids on the talonid (e.g., mesially to the entoconid or distally to the hypoconid). The $\mathrm{m} 2$ is enlarged in the mesial portion, especially with a great expansion of the mesio-buccal cingulid. The protoconid and the metaconid are equal in size. Distal to the protoconid is a hypoconid with accessory cuspulids on both mesial and lingual sides. The m3 possesses two large cuspulids and a distal accessory one.

The postcranial remains from Kvabebi are generally in a bad state of preservation, so the features of the various bones are difficult to discern. MG 29-2013/458 (K251) and MG 29-2013/ 594 (K241) are the distal epiphysis of the left humeri (Bd: $21.0 \mathrm{~mm}$ and $22.2 \mathrm{~mm}$, respectively), showing a prominent medial epicondyle compared to the lateral one; the trochlea has a sharp ridge. MG 29-2013/594 (K239) is fragmentary ulna (BPC: $8.6 \mathrm{~mm}$ ) that possesses a faint lateral coronoid process, whereas the medial one is round and expanded. The ulna of MG 29-2013/458 (K251) has DPA $=18.5 \mathrm{~mm}$ and $\mathrm{BPC}=9.6 \mathrm{~mm}$. Radius fragments MG 29-2013/458 (K251) and MG 29-2013/ 596 (K232) have $\mathrm{Bp}=11.8 \mathrm{~mm}$ and $13.5 \mathrm{~mm}$, and $\mathrm{Bd}=$ $9.0 \mathrm{~mm}$ and $9.0 \mathrm{~mm}$. Two femur fragments are recorded, MG 29-2013/598 (K501) and MG 29-2013/600(K226); the former $(\mathrm{Bp}=23.3 \mathrm{~mm}$ and $\mathrm{DC}=12.3 \mathrm{~mm})$ shows a large head departing from a short neck. The greater trochanter is high and slender, with a deep trochanteric fossa. The lesser trochanter of MG 29-2013/598 (K501) is prominent. In the distal epiphysis, the lateral condyle is considerably larger than the medial, which is also thinner. There is no proximal epiphysis of the tibiae preserved, but only a diaphysis with the distal portion MG 29-2013/599 (K820), with $\mathrm{Bd}=17.4 \mathrm{~mm}$ and $\mathrm{Dd}=11.9$ $\mathrm{mm}$. The calcaneum MG 29-2013/601 is rather compressed mediolaterally, so that the sustentalum tali is very reduced $(\mathrm{GL}=31.9 \mathrm{~mm}$ ). MG 29-2013/594 and MG 29-2013/597 are metapodial fragments with associated phalanges. MG 29-2013/ 594 measures are: $\mathrm{Mc}$ II $-\mathrm{GL}=39.6 \mathrm{~mm} ; \mathrm{Bp}=4.7 \mathrm{~mm}$; $\mathrm{Dp}=7.6 \mathrm{~mm}$; Mc III-GL $=47.4 \mathrm{~mm} ; \mathrm{Bp}=6.3 \mathrm{~mm} ; \mathrm{Dp}=$ $72 \mathrm{~mm} ; \mathrm{Mc} \mathrm{IV}-\mathrm{GL}=46.5 \mathrm{~mm} ; \mathrm{Bp}=4.1 \mathrm{~mm} ; \mathrm{Dp}=6.5 \mathrm{~mm}$; $\mathrm{Mc} \mathrm{V}-\mathrm{GL}=38.6 \mathrm{~mm} ; \mathrm{Bp}=7.5 \mathrm{~mm} ; \mathrm{Dp}=6.3 \mathrm{~mm}$.

Remarks.-Most of the Canidae specimens of Kvabebi are ascribable to the genus Nyctereutes based on the size and 


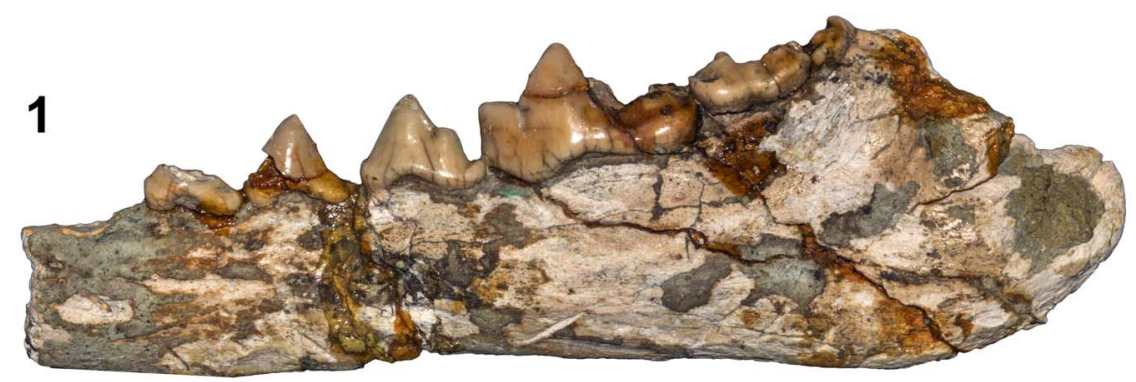

4
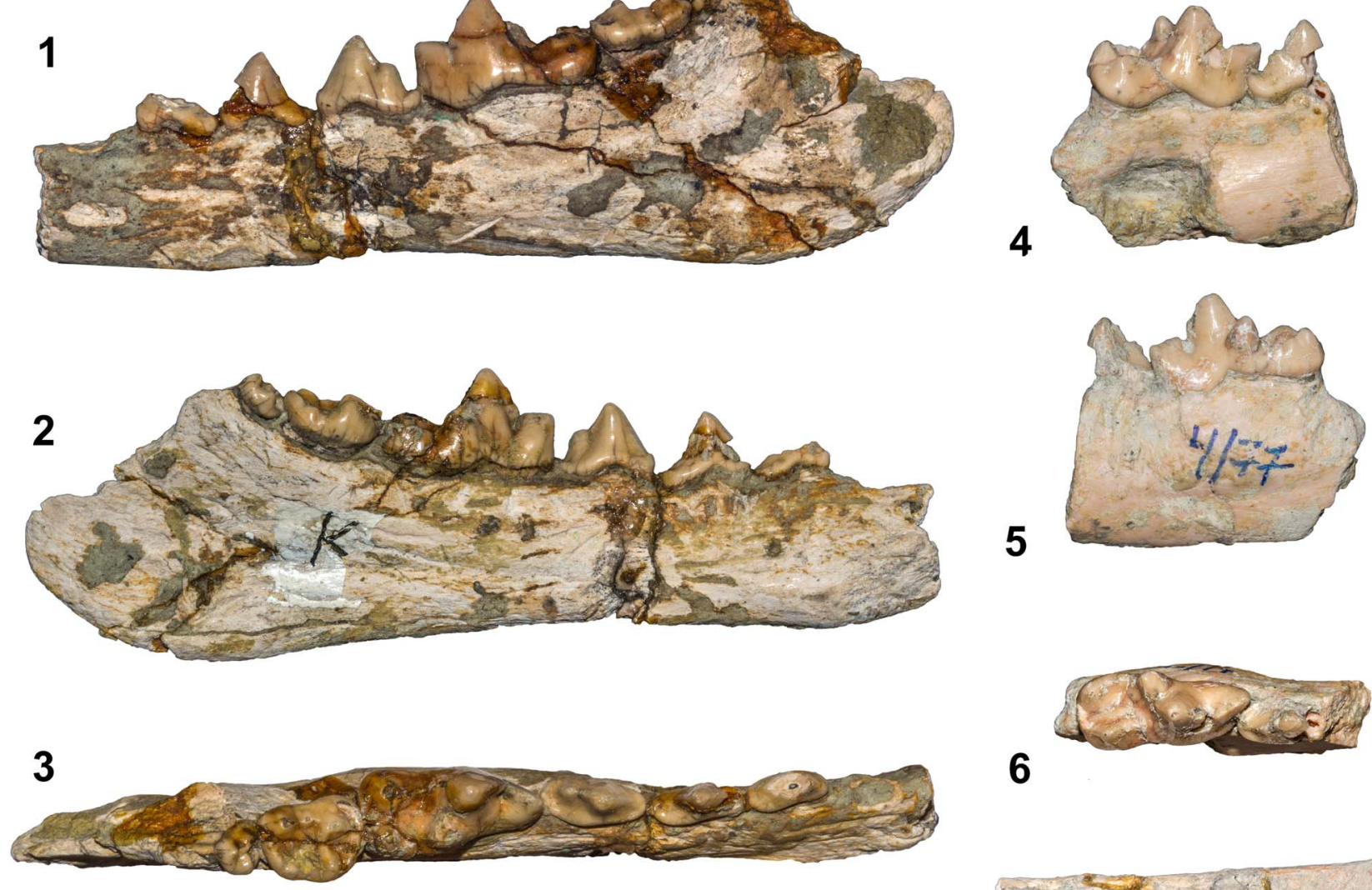

6
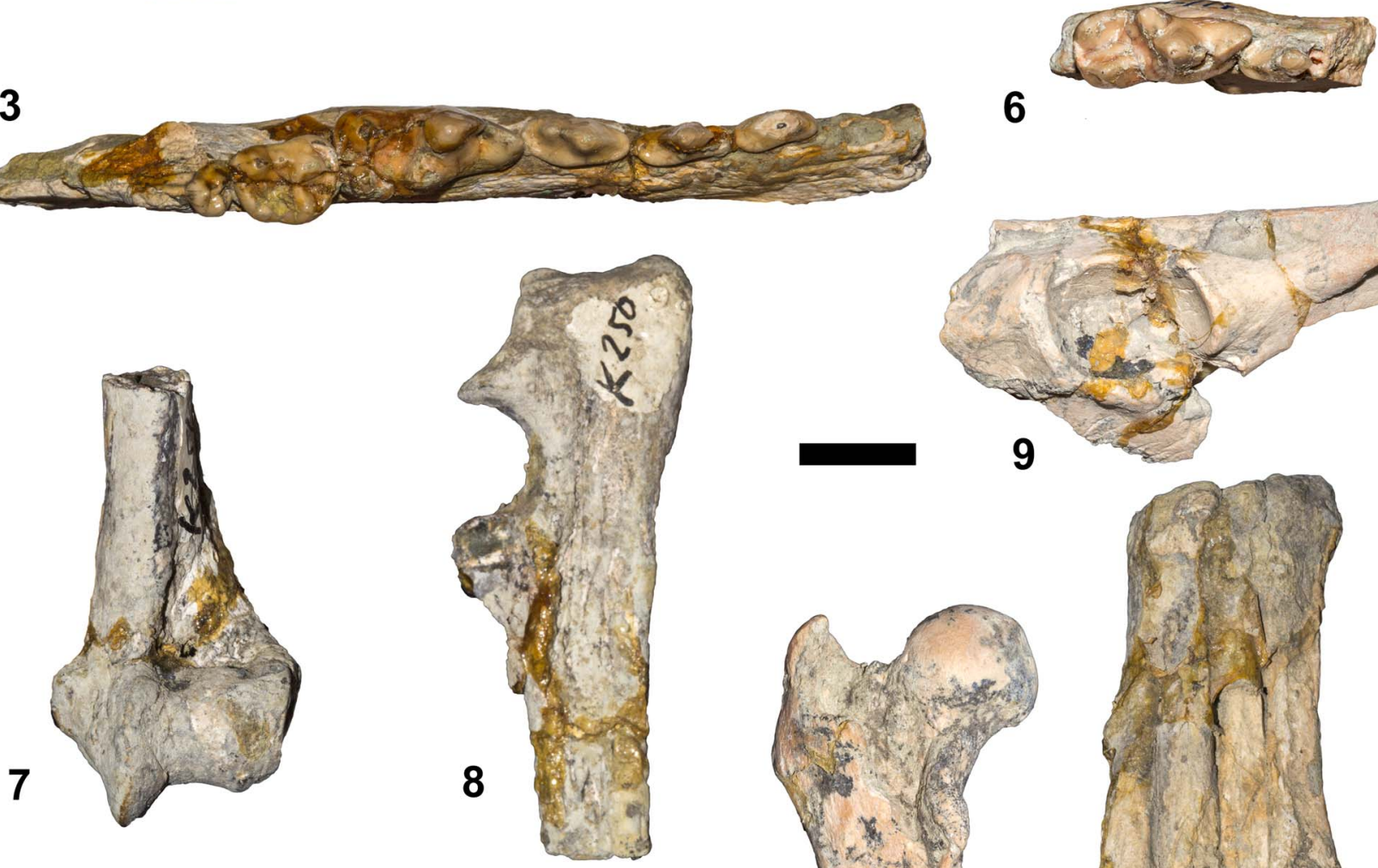

12
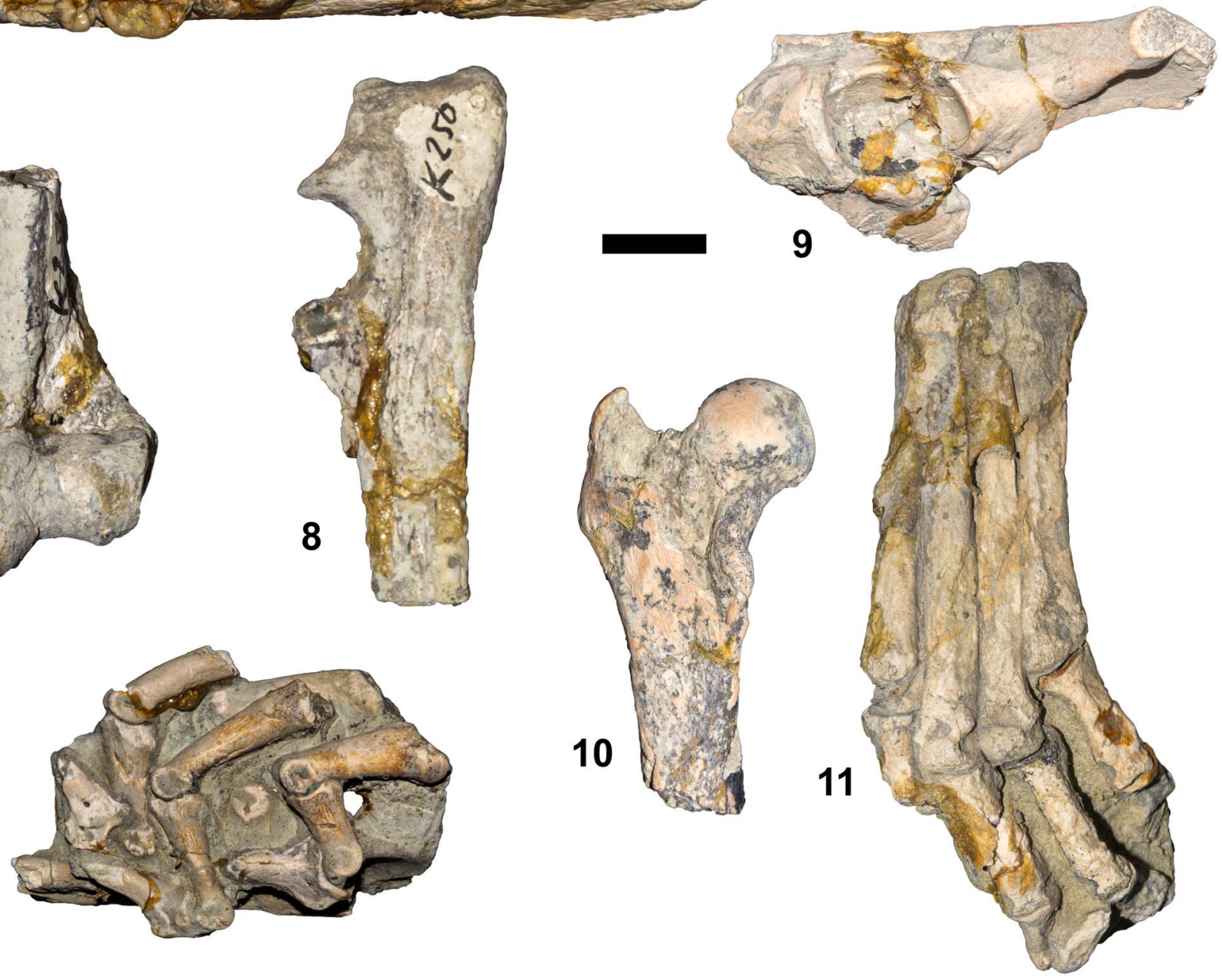
Table 1. Cranial measurements of Nyctereutes megamastoides (Pomel, 1842) from Kvabebi. A-B = akrokranion-basion (height of the cranium without the sagittal crest); $\mathrm{BL}=$ basion-prosthion (basal length of the cranium); $\mathrm{CBL}=$ prosthion-occipital condyles (condylobasal length of the cranium); Ect $=$ ectorbitaleectorbitale (frontal breadth); $\mathrm{ECW}=$ external $\mathrm{C} 1$ alveoli width; $\mathrm{Eu}=$ greatest neurocranium breadth; $\mathrm{FL}=$ prosthion-frontal midpoint $($ facial length); FMW = width of the foramen magnum; GPW $=$ greatest palatal width; GWOC $=$ greatest width of occipital condyles; NcL $=$ akrokranion-frontal midpoint (neurocranium length); $\mathrm{PL}=$ prosthion-staphylion (palatal length); $\mathrm{PoCW}=$ least breadth of postorbital constriction; $\mathrm{SH}=$ skull height (with sagittal crest); $\mathrm{TL}=$ akrokranion-prosthion (total length of the cranium); Zyg = zygion-zygion (zygomatic breadth).

\begin{tabular}{|c|c|c|c|c|c|c|c|c|c|c|c|c|c|c|c|c|}
\hline & $\mathrm{TL}$ & NCL & FL & $\mathrm{Eu}$ & Ect & PocW & SH & A-B & GWOC & $\mathrm{BL}$ & PL & $\mathrm{CBL}$ & $\mathrm{ZyG}$ & ECW & GPW & $\overline{\text { FMW }}$ \\
\hline MG 29-2013/455 (K234) & - & - & - & 42.2 & - & - & 35.2 & 26.8 & - & - & - & - & - & - & - & - \\
\hline MG 29-2013/567 (K4173) & - & 66.3 & - & 46.9 & 43.8 & 27.1 & 43.0 & 34.7 & 23.3 & - & - & - & - & - & - & 10.4 \\
\hline MG $29-2013 / 568$ (K215) & 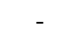 & 59.6 & - & 42.0 & 42.7 & 28.2 & 36.5 & & 23.6 & & & & & & 40.3 & 8.0 \\
\hline MG 29-2013/581 & 129.2 & {$[58.0]$} & 73.5 & 49.1 & 46.1 & 30.3 & 36.6 & - & - & - & 67.4 & - & - & 16.8 & 34.6 & - \\
\hline
\end{tabular}

Table 2. Associated upper teeth measurements of Nyctereutes megamastoides (Pomel, 1842) from Kvabebi. L = mesiodistal length; LCR $=$ upper cheek toothrow length (P1-M2); LMR = upper molar row length (M1-M2); LPR = upper premolar row length (P1-P4); W = buccolingual width.

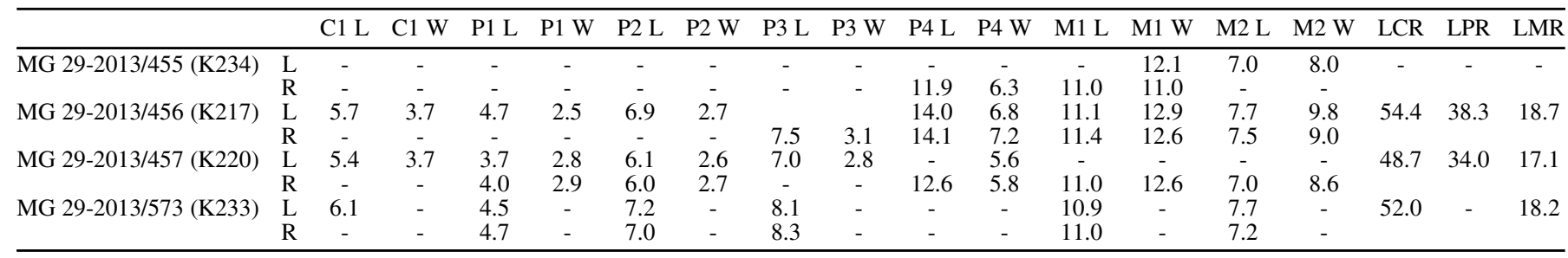

on the morphological features described above. Compared to $N$. procyonoides and to the Eurasian Pliocene species of raccoon dog-like canids, Nyctereutes from Kvabebi is similar in size to $N$. megamastoides, $N$. sinensis, and $N$. donnezani, but smaller than $N$. tingi. Some morphological features (e.g., the high angle of the corpus of the mandible in the region of the subangular lobe, subquadrate M1, mesiodistally enlarged M2, etc.) are suggestive of a derived form of Nyctereutes, thus differing from primitive morphologies like those characterizing $N$. tingi and N. donnezani (e.g., poorly developed subangular lobe, reduced width of upper molars). Therefore, Nyctereutes from Kvabebi is more similar to species like the extant $N$. procyonoides, $N$. sinensis from the Yushe Basin, and N. megamastoides from Western Europe. Among these latter species, N. procyonoides possesses the greatest number of dental differences compared to Nyctereutes from Kvabebi (e.g., the P4 protocone more mesially placed, a stronger parastyle on $\mathrm{P} 4$, proportionally buccolingually shorter M1 and M2, the M1 metacone and metaconule reduced in development, the pointy and higher M1 hypocone, the individualized metaconid and reduced buccolingual width of the talonid on the $\mathrm{m} 1$ ). Nyctereutes sinensis and $N$. megamastoides are similar in size and in morphological features, so they could represent a single taxon with a wide zoogeographic range (Tedford and Qiu, 1991). Nevertheless, as pointed out by Tedford and Qiu (1991), N. megamastoides has a better-developed subangular lobe and more quadrangular upper molars compared to $N$. sinensis. Furthermore, the $\mathrm{P} 4$ protocone of $N$. sinensis lies more mesially when compared to the mesial margin of the tooth, more than it does in N. megamastoides; this species has an equal-sized M1 paracone and metacone, in contrast to those of $N$. sinensis, which appear well developed in F: AM 96759 (Tedford and Qiu, 1991); the latter species does not possess any or strongly reduced protoconule on M1, which is present in the Villaroya and Dafnero N. megamastoides; the mesiolingual cingulum on M1 of $N$. sinensis is not continuous and does not form the cuspid-like enlargement on the mesial side of the M1 of $N$. megamastoides; the M2 of the Chinese species is reduced compared to that of $N$. megamastoides, which has a peculiar "D"-like shape; $N$. megamastoides from Villaroya and Dafnero-1 has a large protoconule and protocone and a low metaconule on the M2, whereas $N$. sinensis seems to possess only a large and prominent protocone; the $\mathrm{m} 1$ metaconid of $N$. megamastoides is larger than that of $N$. sinensis; in $N$. megamastoides, the $\mathrm{m} 1$ talonid is considerably enlarged compared to the trigonid, whereas in $N$. sinensis the talonid is not oversized compared to the trigonid; the $\mathrm{m} 2$ is generally slender in $N$. sinensis compared to $N$. megamastoides in which it is oval in shape. The $\mathrm{m} 2$ protoconid and metaconid are subequal in size in $N$. megamastoides, whereas $N$. sinensis has a larger protoconid; this latter species does not possess any accessory cuspulids on the disto-lingual side of $\mathrm{ml}$, whereas $N$. megamastoides generally shows the entoconid and may possess accessory cuspulids. Considering these differences, the Kvabebi raccoon dog can be assigned to Nyctereutes megamastoides.

Cranial, dentognathic, and postcranial measurements of the Nyctereutes sample from Kvabebi are shown in Tables 1-4.

Figure 2. Nyctereutes megamastoides (Pomel, 1842) from Kvabebi. MG 29-2013/820, left hemimandible, in buccal (1), lingual (2), and occlusal (3) views; MG 29-2013/592 (K4177), right hemimandible fragment, in buccal (4), lingual (5), and occlusal (6) views; MG 29-2013/458, left humerus (K251) and ulna (K250), in caudal (7) and right lateral (8) views; MG 29-2013/602 (K503), right pelvis, in lateral view (9); MG 29-2013/600 (K226), right femur, in dorsal view (10); MG 29-2013/597 (K253), left metacarpals with phalanges, in dorso-lateral view (11); MG 29-2013/460 (K254), left phalanges, in lateral view (12). Scale bar $=1 \mathrm{~cm}$. 
Table 3. Mandibular measurements of Nyctereutes megamastoides (Pomel, 1842) from Kvabebi. LLMR, length of the lower molar row (m1-m3); M m1 B, mandibular corpus breadth below midpoint of m1; M p4 H, mandibular corpus height distal to p4 alveolus; m1-m2 $\mathrm{L}$, length of the first and second lower molars; p2-p4 L, length of premolar row, starting from $\mathrm{p} 2$.

\begin{tabular}{lcccccc}
\hline & & $\mathrm{M}$ and $\mathrm{P}_{4} \mathrm{H}$ & $\mathrm{B} \mathrm{m}$ and $\mathrm{m} 1$ & $\mathrm{p} 2-\mathrm{p} 4 \mathrm{~L}$ & LLMR & $\mathrm{m} 1-\mathrm{m} 2 \mathrm{~L}$ \\
\hline MG 29-2013/588 (K221) & $\mathrm{L}$ & 14.1 & 7.0 & - & 26.0 & 22.4 \\
MG 29-2013/589(K224) & $\mathrm{R}$ & 13.7 & 5.8 & - & - & - \\
MG 29-2013/591 (K214) & $\mathrm{R}$ & 13.1 & 6.7 & - & - & - \\
MG 29-2013/592(K4177) & $\mathrm{R}$ & 13.6 & 7.9 & - & - & - \\
MG 29-2013/820 & $\mathrm{L}$ & 12.5 & & 24.4 & 28.2 & 24.1 \\
\hline
\end{tabular}

Table 4. Associated lower teeth measurements of Nyctereutes megamastoides (Pomel, 1842) from Kvabebi. L = mesiodistal length; m1 trL = trigonid of m1; $\mathrm{m} 1 \mathrm{tdL}=$ talonid of $\mathrm{m} 1 ; \mathrm{W}=$ buccolingual width.

\begin{tabular}{|c|c|c|c|c|c|c|c|c|c|c|c|c|c|c|c|c|c|c|}
\hline & & $1 \mathrm{~L}$ & $\mathrm{~W}$ & $1 \mathrm{~L}$ & $1 \mathrm{~W}$ & $2 \mathrm{~L}$ & $2 \mathrm{~W}$ & $3 \mathrm{~L}$ & $3 \mathrm{~W}$ & $4 \mathrm{~L}$ & $\mathrm{p} 4 \mathrm{~W}$ & $\mathrm{n1 \textrm {L }}$ & $\mathrm{m} 1 \mathrm{w}$ & $\mathrm{m} 1 \mathrm{trL}$ & $\mathrm{m} 2 \mathrm{~L}$ & $\mathrm{~m} 2 \mathrm{~W}$ & $\mathrm{~m} 3 \mathrm{~L}$ & $\overline{\mathrm{m} 3 \mathrm{~W}}$ \\
\hline MG 29-2013/588(K221) & $\mathrm{L}$ & 4.5 & 3.6 & 3.6 & 2.1 & - & - & - & - & - & - & 14.9 & 5.8 & - & 7.9 & 5.8 & 4.4 & 3.8 \\
\hline MG 29-2013/591 (K214) & $\mathrm{R}$ & - & - & - & - & - & - & - & - & - & - & 14.8 & 6.7 & 9.5 & - & - & - & - \\
\hline MG 29-2013/592 (K4177) & $\mathrm{R}$ & - & - & - & - & - & - & - & - & - & - & 14.8 & 6.6 & 8.4 & - & - & - & - \\
\hline MG $29-2013 / 606$ & $\mathrm{R}$ & 7.1 & 4.0 & - & - & - & - & - & - & - & - & - & - & - & - & - & - & - \\
\hline MG 29-2013/820 & $\mathrm{L}$ & - & - & - & - & 7.2 & 3.0 & 8.1 & 3.1 & 9.1 & 4.2 & 15.9 & 7.7 & 9.2 & 8.7 & 7.5 & 4.1 & 4.4 \\
\hline
\end{tabular}
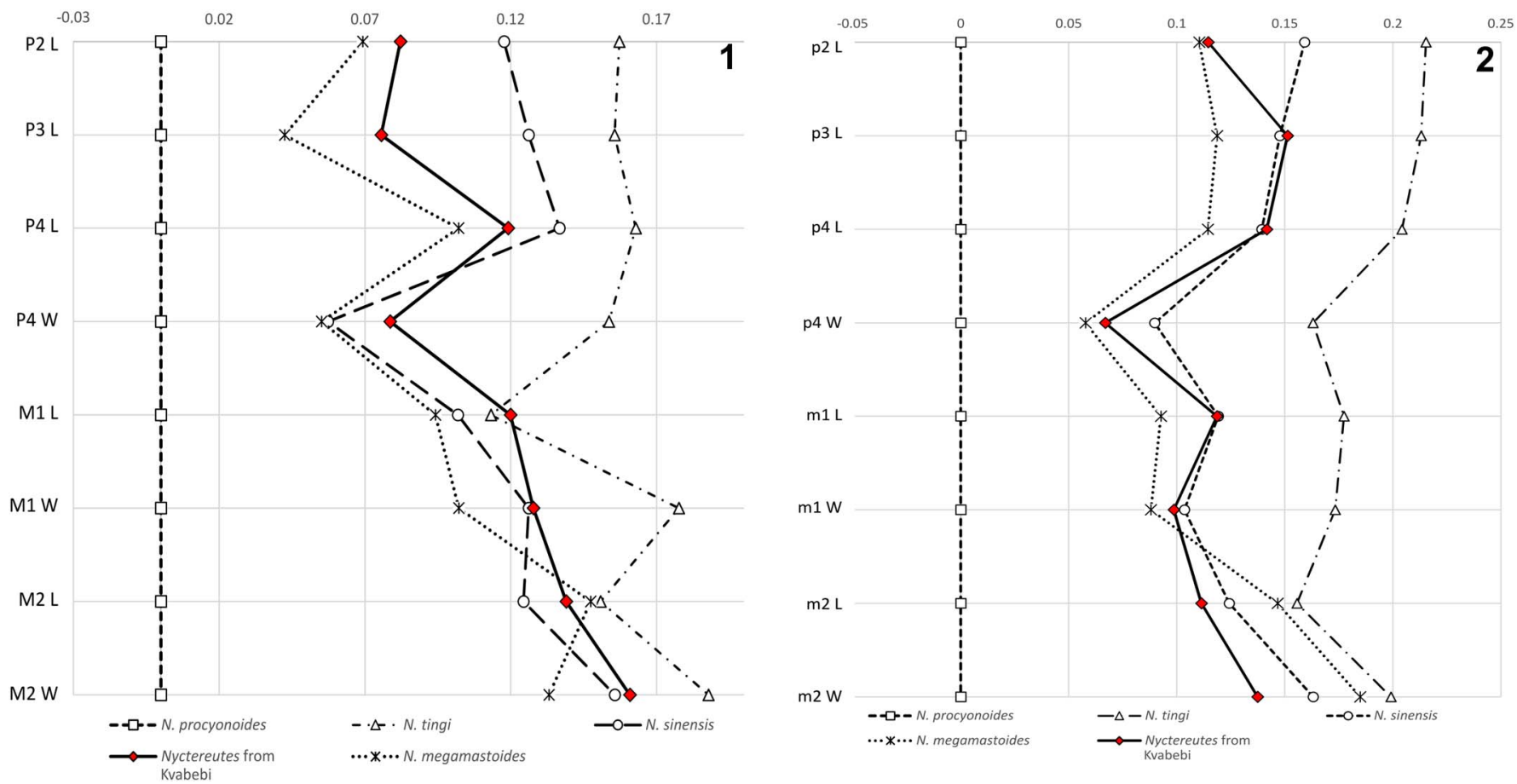

Figure 3. Log-ratio diagrams based on selected upper (1) and lower teeth (2) variables in the described Kvabebi material, as well as in other Pliocene and extant species of Nyctereutes (N. sinensis, N. tingi, and N. megamastoides; data taken from the literature: Tedford and Qiu, 1991; Monguillon et al., 2004) as compared to the extant $N$. procyonoides (used as the reference baseline).

The log-ratio diagrams (Fig. 3.1, 3.2) were used to compare the mean dental measures of Nyctereutes from Kvabebi to those of the extant $N$. procyonoides and other Eurasian Pliocene species, using $N$. sinensis from the Yushe Basin (Tedford and Qiu, 1991) as a standard reference. On the one hand, these diagrams show that Nyctereutes from Kvabebi differs considerably both in size and proportions from $N$. procyonoides and from $N$. tingi, the former being much smaller (as expected), and the latter substantially larger, than the Kvabebi raccoon-dog. On the other hand, the graphs allow an appreciation of how the Kvabebi sample is similar in size and proportion to both $N$. sinensis and $N$. megamastoides, although with a much greater affinity to the latter. This provides additional support for the taxonomic interpretation of the Kvabebi material as Nyctereutes megamastoides.

\section{Genus Vulpes Frisch, 1775}

Vulpes cf. V. alopecoides Major, 1875

1972 Canis sp. Vekua, p. 50, pl. 3, fig. 7.

Holotype.-The holotype of Vulpes alopecoides comes from Tasso (early Pleistocene), Upper Valdarno Basin, Tuscany, Italy.

Materials.-MG-29-2013/461 (K260) right hemimandible fragment with $\mathrm{m} 1$ and $\mathrm{m} 2$. 


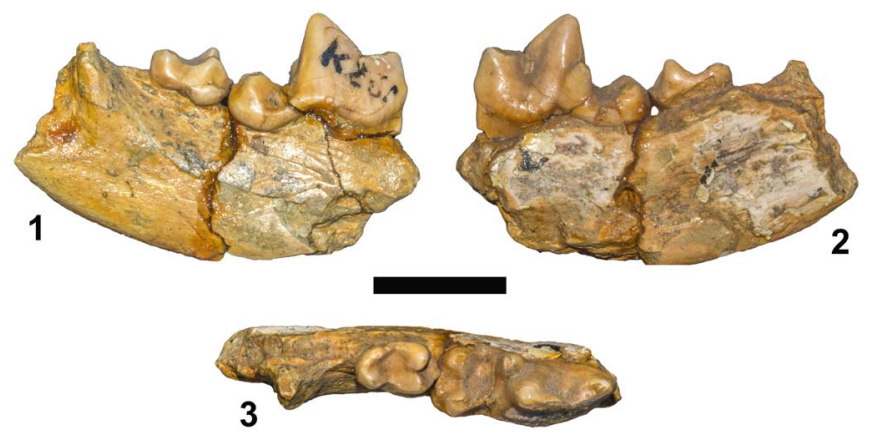

Figure 4. Vulpes cf. V. alopecoides from Kvabebi. MG-29-2013/461 (K260), right hemimandible fragment, in buccal (1), lingual (2), and occlusal (3) views. Scale bar $=1 \mathrm{~cm}$.

Description.-The fragment MG-29-2013/461 (K260) is very small in dimensions compared to the other specimens from Kvabebi. The ventral margin of the corpus of the mandible is preserved in a small, curved portion below the $\mathrm{m} 2$ (e.g., Fig. 4). The $\mathrm{m} 1$ possesses a proportionately high paraconid, a higher and distally curved protoconid and a prominent, slightly individualized metaconid. The latter is in line with the distal margin of the protoconid, so it is not visible in buccal view. The talonid basin is deep, with a large hypoconid and a smaller entoconid. These cuspulids are of the same height and are connected by a cristid. On the buccal side, there is a cingulid. The $\mathrm{m} 2$ is beanshaped, with a larger mesial part compared the distal. The protoconid has a larger base than the metaconid, but both cuspulids have the same height. Mesial to the protoconid is a prominent cristid that ends in a faint accessory cuspulid. On the mesiobuccal side, a cingulid is well developed. Distal to the protoconid is a large hypoconid, and the lingual side is bounded by a cristid with a low entoconid. MG 29-2013/461 (K260) measurements are as follows: $\mathrm{m} 1 \mathrm{~L}=131 \mathrm{~mm} ; \mathrm{m} 1 \mathrm{~W}=5.5 \mathrm{~mm}$; $\operatorname{trm} 1 \mathrm{~L}=8.5 \mathrm{~mm} ; \mathrm{m} 2 \mathrm{~L}=6.2 \mathrm{~mm} ; \mathrm{m} 2 \mathrm{~W}=4.4 \mathrm{~mm} ; \mathrm{M} \mathrm{m} 1$ $\mathrm{B}=4.5 \mathrm{~mm} ; \mathrm{M} \mathrm{m} 1 \mathrm{H}=11.1 \mathrm{~mm}$.

Remarks.-The extant species $V$. vulpes is larger in size compared to the smallest canid from Kvabebi. Moreover, it possesses several features (such as an individualized and large metaconid, a high and pointy accessory cuspulid between entoconid and metaconid, and an oval-shaped $\mathrm{m} 2$ with numerous distal accessory cuspulids) that cannot be found in MG 29-2013/461 (K260). Unlike the arctic fox V. lagopus, the smallest Kvabebi canid possesses the $\mathrm{m} 1$ entoconid and hypoconid close to one another, a reduced talonid basin, and a slender $\mathrm{m} 2$. Compared to V. praecorsac from the Odessa catacombs and Püspökfürdö (Kormos, 1932; Odintzov, 1965), MG 29-2013/ 461 (K260) shows some differences (e.g., a slender $\mathrm{m} 1$ protoconid, in lateral view; the lower carnassial less compressed buccolingually; and the $\mathrm{m} 2$ more elongated mesiodistally and bean-shaped in occlusal view, with a reduced talonid portion compared to the large trigonid). Following the discussion in Madurell-Malapeira et al. (2009), some of the distinctive features of $V$. praeglacialis are: (1) a large and individualized m1 metaconid; (2) a wide bicuspid talonid with a larger hypoconid; and (3) a large and wide $\mathrm{m} 2$, with the protoconid larger than the metaconid. All these features contrast with those of MG 29-2013/461 (K260). In fact, the morphology of the $\mathrm{m} 1$ of closely resembles that of $V$. alopecoides from Pirro Nord and Dafnero-1 in general shape, with the distally inclined protoconid, the reduced metaconid, and slightly larger hypoconid compared to the entoconid and the presence of an accessory cuspulid mesial to the entoconid. The talonid of $V$. alopecoides is slightly shorter mesiodistally when compared to the Kvabebi specimen.

The scatter plot of the $\mathrm{m} 1$ length and width of Vulpes is shown in Figure 5. Together with the two extant species, $V$. vulpes and $V$. lagopus, we also include the Eurasian Plio-Pleistocene species $V$. praecorsac, V. praeglacialis, and $V$. alopecoides for comparison.

All the fossil species fall within the variability of extant $V$. lagopus and are generally smaller than $V$. vulpes. Vulpes praecorsac is characterized by extremely reduced dimensions compared to the other two fossil species, being at the lower dimensional range of the extant $V$. lagopus. Vulpes praeglacialis and $V$. alopecoides are comparable in size. An additional scatter plot of $\mathrm{m} 1 \mathrm{~L}$ and the ratio of $\mathrm{m} 1 \mathrm{~W} / \mathrm{L}$ allows an appreciation of the differences in robustness of the lower carnassial of Vulpes fossil species, showing that the Kvabebi specimen, like V.alopecoides, is characterized by stouter proportions of the $\mathrm{m} 1$ (Fig. 6).

MG 29-2013/461 (K260) falls within the upper dimensional range of the early Pleistocene $V$. alopecoides sample and shares with the same species a comparable degree of robustness. Based on its morphological features, size, and proportions, we are prone to identify this specimen as Vulpes cf. V. alopecoides.

Tribe Canini Fischer von Waldheim, 1817 Genus Eucyon Tedford and Qiu, 1996

\section{Eucyon sp.}

1972 Nyctereutes megamastoides Vekua, p. 41.

2009 Nyctereutes megamastoides Agustí et al., p. 3277.

2009 Eucyon sp. Agustí et al., p. 3277.

Materials.-MG 29-1 (K222) neurocranium; MG 29-2013/607 right p4; MG 29-2013/608 left p4; MG 29-2013/603 right m1.

Description.-MG 29-1 (K222) is a neurocranium preserving partial dorsal portions of the orbits and the frontals. The neurocranium (Fig. 7) is globular in shape, with inflated frontal sinuses that expand into the postorbital constriction. Their extension into the frontal is also testified by the dorsal outline of the frontals that bulge in lateral view, at level of the postorbital processes. The inflation of the frontal sinuses is also revealed by the smoothness of the parasagittal crest on top of them. In caudal view, the supraoccipital shield is fan-shaped, with an expansion at level of the mastoid process. The inions fail to overhang the condyles.

The two premolars show high protoconids, slightly arched lingually; on their distal sides. There is a distal individualized and large cuspulid, which is not in line with the protoconid, but sits sits slightly buccally. Distally, there is a cuspulid-like cingulid. In the occlusal view, the $\mathrm{m} 1$ is elongated mesio-distally and slender. The paraconid is low, whereas the protoconid is high and slightly inclined backwards. The metaconid is reduced in height and rather individualized from the protoconid; it is positioned slightly 


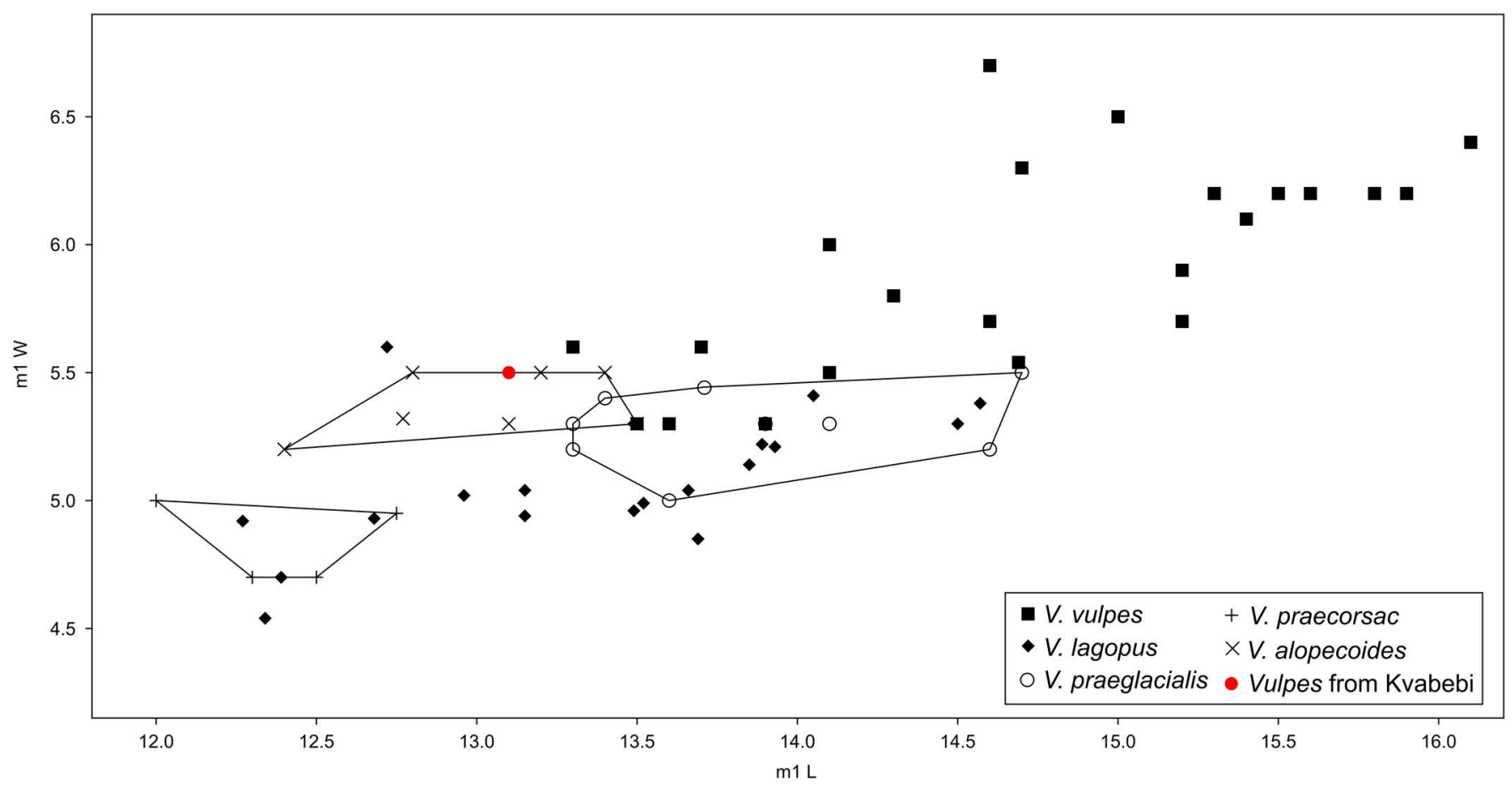

Figure 5. Scatter-plot diagram of the $\mathrm{m} 1$ length and width in extant and fossil species of the genus Vulpes. Symbols are explained in the legend.

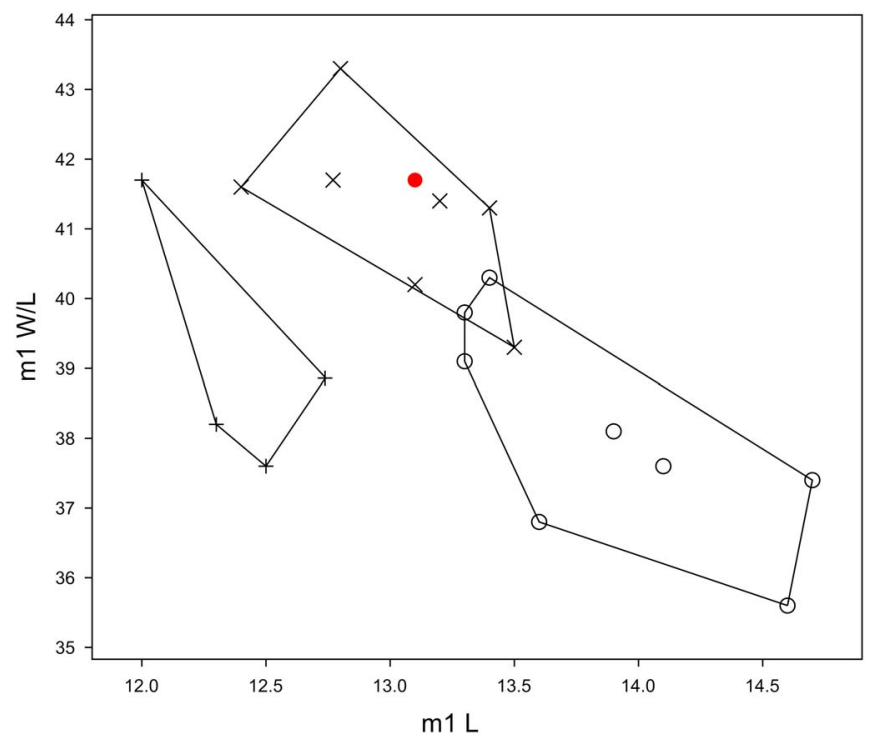

Figure 6. Scatter-plot diagram of the $\mathrm{m} 1$ width and $\mathrm{m} 1$ width/length ratio in fossil species of Vulpes. Symbols are the same as in Fig. 5.

distally compared to the distal wall of the protoconid, so that, in buccal view, it is visible behind it. The hypoconid is large and occupies almost all the talonid and has a faint accessory cuspulid on its distal side. The entoconid is reduced. There is a weak cristid connecting the talonid cuspulid. The $\mathrm{m} 1$ possesses a buccal cingulid.

Remarks.-Cranial and dentognathic measurements of Eucyon from Kvabebi are shown in Table 5. The neurocranium MG 29-1 (K222) possesses inflated frontal sinuses, in contrast to all other cranial fragments recovered from Kvabebi.
As shown in Figure 7, N. megamastoides crania (e.g., MG 29-2013/567 [K4173]) generally have marked postorbital constrictions in shape of a strong incision, in dorsal view. On the contrary, the postorbital constriction of MG 29-1 (K222) is slightly distinct. Furthermore, the dorsal portion of the frontals is bulging, compared to the depression visible in $N$. megamastoides. In caudal view, the supraoccipital shield in Eucyon is fan shaped (Fig. 7.10), whereas that of $N$. megamastoides is subrectangular (Fig. 7.11).

The p4 of Nyctereutes possess a short protoconid characterized by large mesial and distal sides (resulting in a low isosceles triangular shape in the buccal shape) and a distal accessory cuspulid that is almost entirely attached to the protoconid. In contrast, GM 29-2013/607 and GM 29-2013/ 608 show a high and slender protoconid with a prominent and individualized distal accessory cuspulid, features similar to those of Canini species. Because of its small size (Table 5) and some missing morphological features (e.g., weak cristid between hypoconid and entoconid), MG 29-2013/603 cannot be attributed to Canis. The paraconid is large mesiodistally with a subvertical mesial margin similar to E. odessanus from Alatini, unlike E. davisi and E. zhoui from Yushe and E. adoxus from Roussillon, which is shorter and distally inclined. Eucyon zhoui and E. adoxus possess very stout protoconids and larger metaconids compared to the specimen from Kvabebi. Furthermore, E. adoxus has a prominent cristid on the buccodistal side of the protoconid that is hardly visible in other Eucyon species. Eucyon marinae from Muhor-Erig, disregarding its larger size, has a considerably more individualized and larger metaconid compared to MG 29-2013/603, which is also distally pointed.

The talonid cuspids of the Kvabebi Eucyon bear resemblance to those of E. davisi and E. odessanus, with a large 

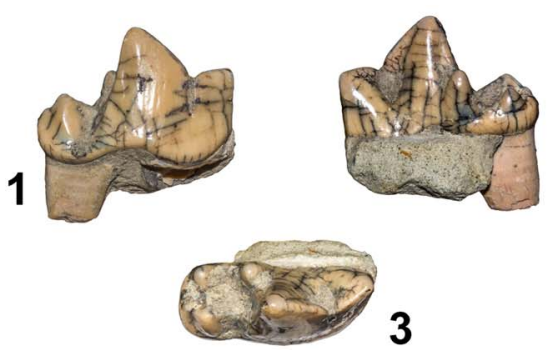

3

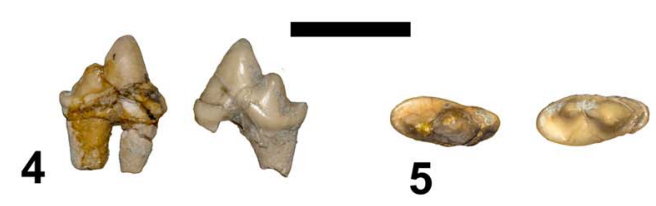

2

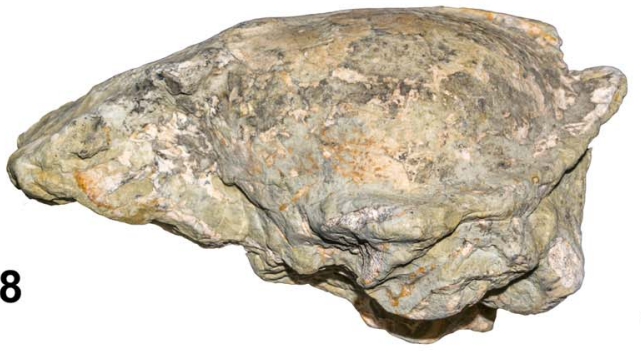

10
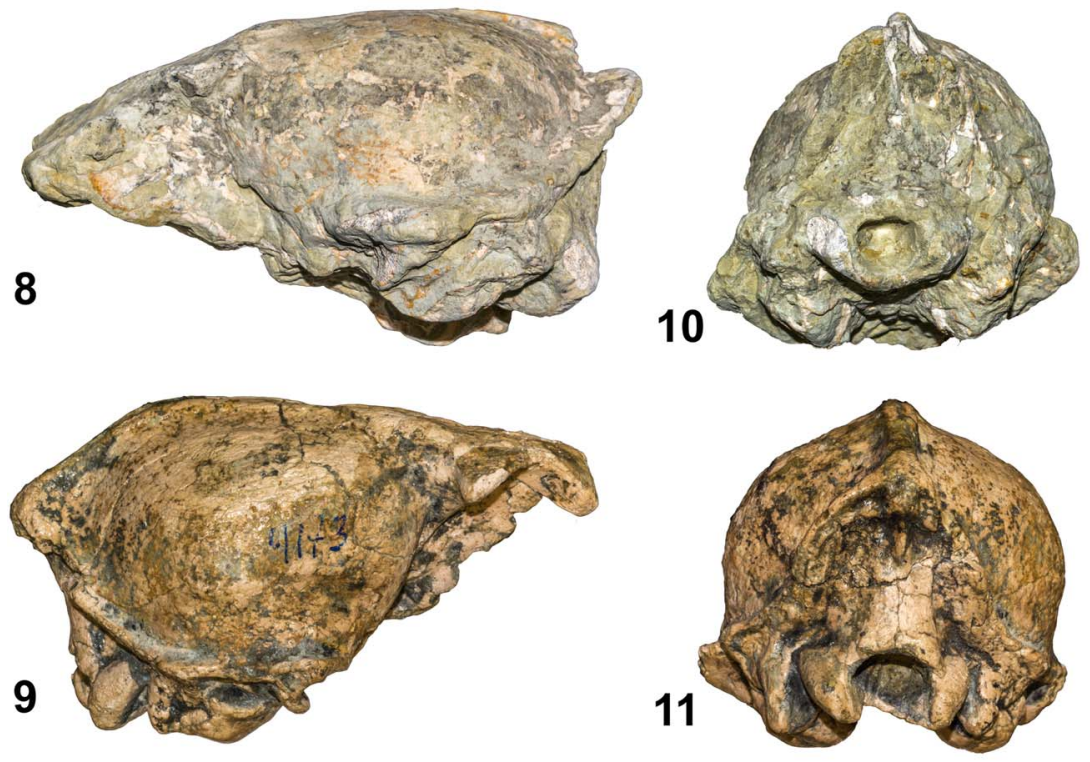
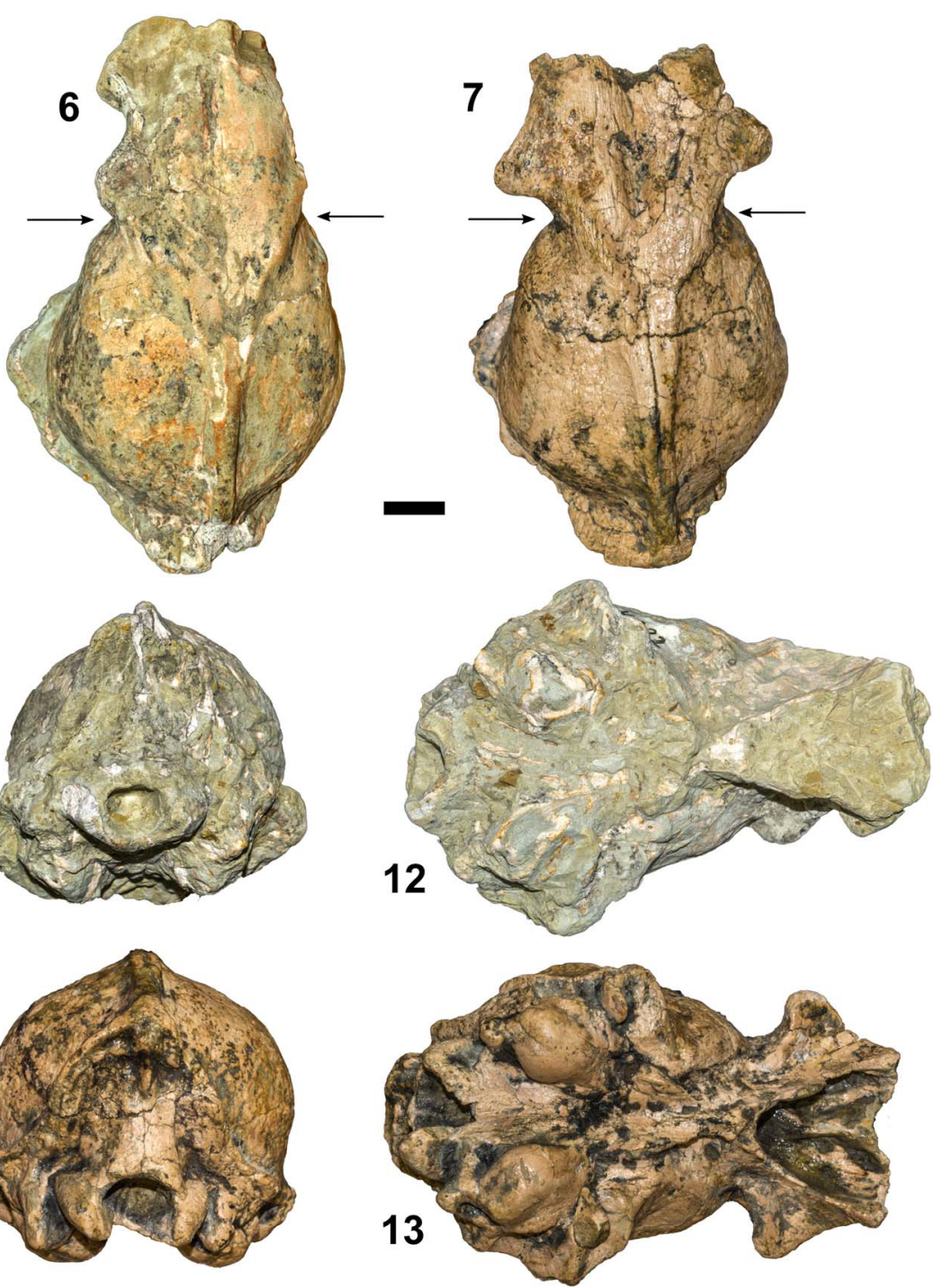

Figure 7. Eucyon sp. from Kvabebi. MG 29-2013/603, right m1, in buccal (1), lingual (2) and occlusal (3) views; MG 29-2013/607-608, right and left p4, in buccal (4) and occlusal (5) views. Comparison between two neurocranial fragments: Eucyon sp. MG 29-1 (K222) (6, 8, 10, 12) and N. megamastoides MG 29-2013/567 $(\mathrm{K} 4173)(\mathbf{7 , 9 , 1 1 , 1 3})$, in dorsal $(\mathbf{6 , 7})$, left lateral $(\mathbf{8})$, right lateral $(\mathbf{9})$, caudal $(\mathbf{1 0}, \mathbf{1 1})$ and ventral $(\mathbf{1 2}$, 13) views. Arrows highlight the morphology of the frontals at the level of the postorbital constriction and postorbital processes. Scale bar $=1 \mathrm{~cm}$.

Table 5. Summarizing table of Eucyon sp. measurements from Kvabebi. Eu = greatest neurocranium breadth; FMW = width of the foramen magnum; GWOC = greatest width of occipital condyles; $\mathrm{L}=$ mesiodistal length; $\mathrm{NcL}=$ akrokranion-frontal midpoint (neurocranium length); PoCW = least breadth of postorbital constriction; $\mathrm{SH}=$ skull height (with sagittal crest); $\mathrm{W}=$ buccolingual width.

\begin{tabular}{llrllllllll}
\hline & & L & W & trL & NCL & Eu & PoCW & SH & GWOC & FMW \\
\hline MG 29-1 (K222) & neurocranium & & & & 61.7 & 46.5 & 29.8 & 45.4 & 24.4 & {$[10.0]$} \\
MG 29-2013/603 & L & m1 & 16.1 & 6.6 & 10.8 & & & & & \\
MG 29-2013/607 & R & p4 & 8.9 & 3.7 & & & & & & \\
MG 29-2013/608 & L & p4 & 9.3 & 4.2 & & & & & & \\
\hline
\end{tabular}

hypoconid and the entoconid is reduced and placed rather lingually. In fact, E. zhoui possesses a thinner talonid (reduced in buccolingual width), whereas E. marinae and E. adoxus have better-developed entoconids. Unlike the majority of Eucyon species analyzed, MG 29-2013/603 does not possesses accessory cuspulids in the talonid, apart from a small one on the distal side of the hypoconid, A comparable condition occurs in the E. odessanus mandibles of Alatini.

Species variability of the lower carnassial of the Pliocene Eucyon species from Eurasia is reported in the scatter diagram of Figure 8.1. MG 29-2013/603 is smaller than the lower carnassial of all Eurasian eucyons (E. marinae, E. zhoui, E. davisi, E. minor, and E. adoxus). Eucyon odessanus shows a wide dimensional range, and is proportionally slender when compared with the other species. Our specimen falls among the shortest individuals of E. odessanus range, although differing for the relatively wider carnassial. Given its relatively small size and robustness (e.g., Fig. 8.2), we prefer to leave open the specific attribution of the Kvabebi sample, referring to it as Eucyon sp. 

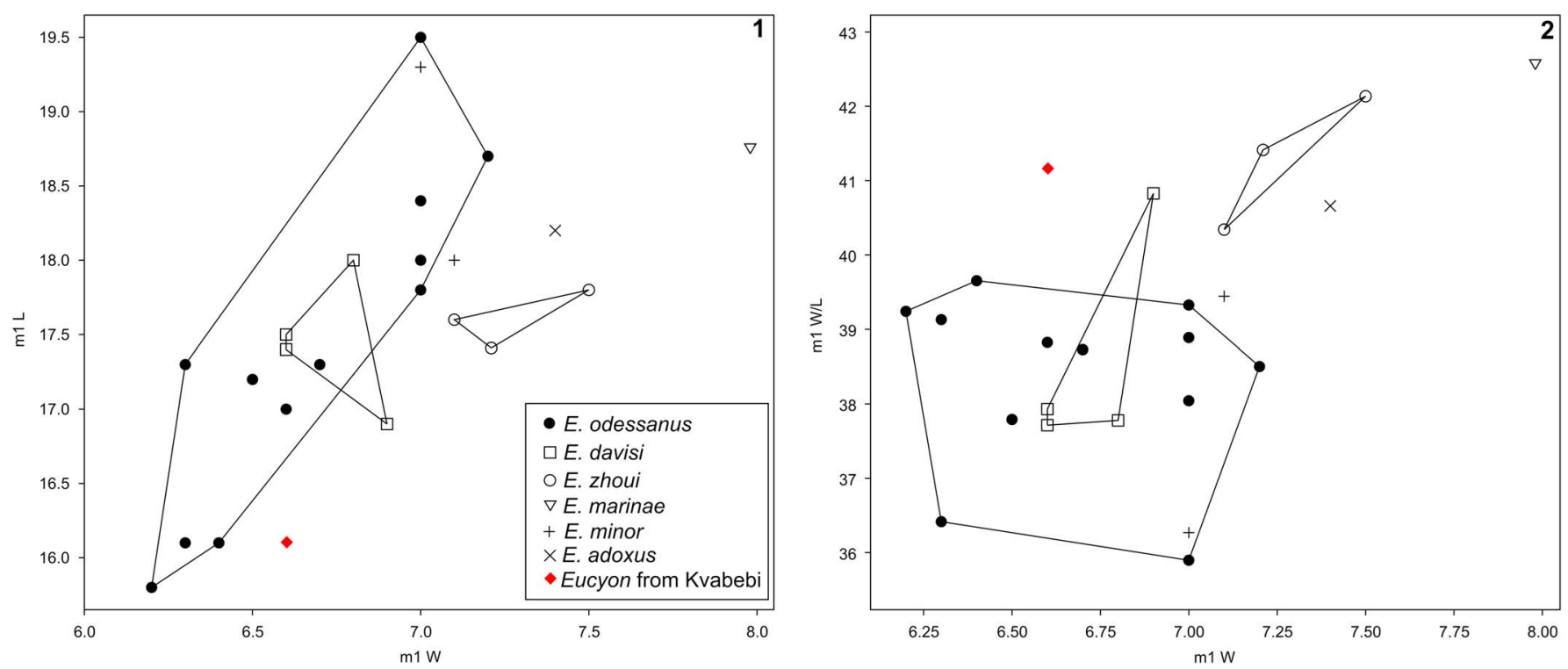

Figure 8. Scatter-plot diagrams of the $\mathrm{m} 1$ length and width (1) and the $\mathrm{m} 1$ width and $\mathrm{m} 1$ width/length ratio (2) in species of the genus Eucyon. Symbols are explained in the legend.

\section{Discussion}

Vekua (1972), who was the first to report canid material from Kvabebi, described several cranial and postcranial elements of Nyctereutes megamastoides and a single hemimandible fragment identified as Canis sp. Our revision confirms, in general terms, these original taxonomic attributions (Vekua, 1972; as updated in Agustí et al., 2009), with additional recognition of a third taxon (Vulpes cf. V. alopecoides).

The occurrence of three sympatric canids is not surprising, since the family shows a great degree of sympatry. At present, Africa, Asia, and South America support the greatest canid diversity, with $>10$ living species for each continental area. The red foxes, golden jackals, and gray wolves are each sympatric with more than ten other canids (from different geographical regions) within one location; however, canid diversity is usually limited to a maximum of four or five species (Sillero-Zubiri and Macdonald, 2004). The fossil record of canid diversity does not contradict this rule, and the Kvabebi record documents a guild of three sympatric canids.

Nyctereutes.-The first occurrence of Nyctereutes is in early Pliocene, with the species Nyctereutes tingi from the Yushe Basin and Nyctereutes donnezani from Western European localities. Subsequently, a more derived species ( $N$. sinensis) appears in some Chinese sites, together with the more primitive $N$. tingi (Teilhard de Chardin and Pei, 1941). By the late early-middle Pleistocene, $N$. sinensis seems to have been replaced by another derived taxon (Nyctereutes sp. in Tedford and Qiu, 1991). In contrast to the coexistence in Asia of primitive and derived forms, in late Pliocene localities in Western European (e.g., San Giusto, Villaroya, Perrier-Etouaires) raccoon dog-like canids are represented by the derived species $N$. megamastoides (Bartolini Lucenti, 2017). This species, probably related to $N$. donnezani, may be regarded as the European counterpart of $N$. sinensis for the retention of comparable derived features.

In the early Pleistocene, there is no or little record of Nyctereutes in Eurasia. The extant $N$. procyonoides appears in the Middle Pleistocene deposits of Zhoukoudian (localities 1 and 13). Even though the phylogenetic relationships of late Pliocene Eurasian species of Nyctereutes are still a matter of debate (see Tedford and Qiu, 1991; Monguillon et al., 2004), we deem a closer relation plausible between the extant $N$. procyonoides and $N$. sinensis. The occurrence in the Kvabebi sample of Nyctereutes megamastoides, as identified by Vekua (1972), testifies to the wide geographic range expansion of this western European taxon.

Recently, Asahara and Takai (2016) attempted to infer dietary preferences in extant and extinct Nyctereutes species using the ratio of $\mathrm{m} 2$ and $\mathrm{m} 1$ surfaces (see also Kavanagh et al., 2007). Their analyses confirmed that primitive species like $N$. donnezani and $N$. tingi had omnivorous diets. In addition, the authors found that $N$. sinensis had a more carnivorous $\mathrm{m} 2 / \mathrm{m} 1$ score than for $N$. megamastoides, suggesting a more omnivorous diet for the latter. Using the methodology of Asahara and Takai (2016), Nyctereutes from Kvabebi possesses an $\mathrm{m} 2 / \mathrm{m} 1$ of $\sim 0.53$, intermediate between the two derived species. The Kvabebi sample fits with the general framework proposed by Asahara and Takai (2016), in which members of the genus Nyctereutes underwent dietary transitions or had considerable dietary plasticity in their evolution.

Vulpes.-The genus Vulpes appeared in the late Miocene (ca. 9 Ma, Hemphillian) of North America (Tedford et al., 2009). As with other members of the subfamily Caninae, it expanded its range early into the Old World, as testified by the African species Vulpes riffautae de Bonis et al., 2007 from the late Miocene Toros-Menalla site and by the early Pliocene Chinese Vulpes beihaiensis Qiu and Tedford, 1990 from the Yushe Basin, as well as Vulpes qiuzhudingi Wang et al., 2014 from the Tibetan Plateau (the Zanda and Kundun basins). This latter large-sized species possesses remarkable hypercarnivorous adaptations, suggesting a close relationship to the extant $V$. lagopus.

The earliest European record of Vulpes is that of early-late Pliocene $V$. praecorsac in the Odessa catacombs (MN 15, Odintzov, 1965). This small-sized fox has been historically 
considered the ancestor of the extant Vulpes corsac (Linnaeus, 1768) (see Kormos, 1932). Another well-known European species is V. alopecoides described by Major, 1975 from Tasso (Upper Valdarno), and recovered from St. Vallier, Senéze, France (Viret, 1954), and Villaroya and La Puebla de Valverde, Spain (Kurtén and Crusafont Pairó, 1977). Kurtén (1968) suggested the synonymy between $V$. alopecoides and $V$. praeglacialis. Nevertheless, the literature reveals no unanimous opinion on the status of these two species (Bonifay, 1971; Rabeder, 1976; García and Arsuaga, 1999). The relationship between the two taxa is beyond the scope of this paper; therefore, we have included both in the comparative analyses. MG 29-2013/461 represents the first occurrence of a member the vulpine taxon $V$. alopecoides, the most widespread fox species in the early Pleistocene of Western Europe.

Eucyon.-The genus Eucyon appears in the late Miocene (late Clarendonian) record of North America with the species Eucyon davisi (Merriam, 1911). Its geographic range remained limited to North America until the latest Miocene, when the genus spread into the Old World, occurring in Central Asia, Africa, and Western Europe (the "Eucyon event", Sotnikova and Rook, 2010). Eucyon davisi disappeared in North America in the earliest Pliocene (latest Hemphillian), and survived into the early Pliocene of eastern Asia (China and Mongolia). The genus Eucyon reached a relative high diversity in the Pliocene of Eurasia (Rook, 2009; Sotnikova and Rook, 2010), surviving until the late Pliocene in China (E. minor), Mongolia (E. marinae), Tadzhikistan (E. kuruksaensis), Kazakhstan (Eucyon cf. E. odessanus), and southeastern Mediterranean regions (E. Eucyon cf. odessanus, Sarikol Tepe, Turkey).

The occurrence of a Eucyon representative within the fauna of Kvabebi completes our knowledge of the late Pliocene history of the advanced eucyons surviving in Western Europe and central Asia. The Kvabebi finding predates the explosive radiation of the wolf- and coyote-sized Canini that took place in Central Asia (reflected in the appearance of Canis teilhardi, C. longdanensis, C. brevicephalus, and Sinicuon cf. S. dubius), which continued until the end of the Pliocene (Qiu et al., 2004; Sotnikova and Rook, 2010).

\section{Conclusions}

The evolutionary history of the Pliocene Canidae in Eurasia is characterized by taxonomic diversification and range expansion. Diversification of Vulpini and Canini showed a maximum in Central Asia at the beginning of the early Pliocene, as evinced by the appearance of several new taxa (Nyctereutes tingi, $V$. beihaiensis, V. qiuzhudingi, Nurocyon chonokhariensis, Eucyon zhoui) and by the increase in frequency of other species (like the well-known Eucyon davisi).

In Western Europe, at the beginning of the Pliocene, the canid record is limited to the primitive vulpine Nyctereutes donnezani. The peak of canid diversification in Western Europe is recorded later in the early Pliocene, during the late Ruscinian (MN 15), with the differentiation of the advanced raccoon-dog Nyctereutes megamastoides, the appearance of the small fox V. praecorsac, and the emergence of the enigmatic "Canis" michauxi, together with the advanced Eucyon adoxus and Eucyon odessanus.
The revision of the Kvabebi assemblage documents the earliest occurrence of the typical (later) early Pleistocene species Vulpes alopecoides in the European fossil record. The contemporary early occurrence at Kvabebi of Vulpes with Nyctereutes and Eucyon clearly supports the established niche partitioning among these three sympatric canids.

\section{Acknowledgments}

We dedicate this paper to the late Professor A. Vekua for his pioneering work on Kvabebi. The Italian Ministry for Foreign Affairs (DGPCC-V) is acknowledged for financially supporting Italian paleontological research in Georgia. Comparative data were partly derived from Projects FR-TAF-3311, BE-TAF-3607, HU-TAF-6520 awarded to LR and SBL by the SYNTHESYS initiative (http://www.synthesys.info) and financed by the European Community Research Infrastructure Action under the FP7 "Capacities" Program.

\section{References}

Agustí, J., Vekua, A., Oms, O., Lordkipanidze, D., Bukhsianidze, M., Kiladze, G., and Rook, L., 2009, The Pliocene-Pleistocene succession of Kvabebi (Georgia) and the background to the early human occupation of Southern Caucasus: Quaternary Science Reviews, v. 28, p. 3275-3280.

Asahara, M., and Takai, M., 2016, Estimation of diet in extinct raccoon dog species by the molar ratio method: Acta Zoologica (Stockholm), v. 98, p. 1-8.

Bartolini Lucenti, S., 2017, Nyctereutes megamastoides (Canidae, Mammalia) from the early and middle Villafranchian (late Pliocene and early Pleistocene) of the Lower Valdarno (Firenze and Pisa, Tuscany, Italy): Rivista Italiana di Paleontologia e Stratigrafia, v. 123, p. 211-218.

Bendukize, O., and Vekua, A., 2012, [The fossil marten from Kvabebi (Eastern Georgia, Kakheti)]. Proceedings of the Georgian National Museum, Natural History and Prehistory section, v. 4, p. 64-70. [in Georgian].

Bonifay, M.F., 1971, Carnivores quaternaires du Sud est de la France: Mémoires du Museé National de Histoire Naturelle, Série C, v. 21, p. 43-377.

Bowdich, T.E., 1821, An Analysis of the Natural Classification of Mammalia for the Use of Students and Travelers: Paris, J. Smith, 115 p.

Burchak-Abramovich, N.I., and Vekua, A.K., 1971, The fossil ostrich from the Akchagi of Georgia: Acta Zoologica Cracoviense, Kraków, v. 16, p. 1-28.

Chkhikvadze, V.M., 1979, [Comparison of turtles of faunas of Kuchurgan and Kvabebi]: Tbilisi, XXII Nauchnaya Sessiya Instituta Paleobiologii, p. 7-9. [in Russian]

Croizet, J.B., and Jobert, A., 1828, Recherches sur les ossemens fossils du Département du Puy-de-Dôme: Paris, Thibaut-Landriot, 224 p.

de Bonis, L., Peigné, S., Likius, A., Mackaye, H.T., Vignaud, P., and Brunet, M., 2007, The oldest African fox (Vulpes riffautae n. sp., Canidae, Carnivora) recovered in late Miocene deposits of the Djurab Desert, Chad: Naturwissenschaften, v. 94, p. 575-580.

de Christol, J., 1834, Recherches sur les caracteres des grandes espèces de rhinocéros fossiles: Montpellier, Jean Martel Ainé, 72 p.

Del Campana, D., 1913, I cani pliocenici di Toscana: Palaeontographia Italica, v. 19, p. 189-254.

Depéret, C., 1890, Les Animaux Pliocènes du Roussillon: Mémoires de la Societé géologique de France, v. 3, p. 5-195.

Devèze, J.S., and Bouillet, J.-B., 1827, Essai Géologique et Minéralogique sur les Environs d'Issoire, Département du Puy-de-Dôme, et Principalement sur la Montagne de Boulade: Avec la Description et les Figures Lithographiées des Ossemens Fossiles qui y Ont Eté Recueillis: Clermont-Ferrand, Imprimerie de Thibaud-Landriot, $104 \mathrm{p}$.

Djikia, N., 1968, Historical Development of Akchagylian Malacofauna from Eastern Georgia: Tbilisi, Mecniereba. [in Russian]

Falconer, H., and Cautley, P.T., 1836, Note on the Felis cristata, a new fossil tiger from the Sivalik Hills: Asiatic Researches, v. 19, p. 135-142.

Fischer von Waldheim, G., 1817, Adversaria Zoologica: Memoires de la Societè imperiale des Naturalistes de Moscou, v. 5, p. 368-428.

Frisch, J.L., 1775, Das Natur-System der vierfüßigen Thiere in Tabellen, darinnen alle Ordnungen, Geschlechte und Arten, nicht nur mit bestimmenden Benennungen, sondern beygesetzten unterscheidenden Kennzeichen angezeigt werden zum Nutzen der erwachsenen Schuljugend: Glogau, C. F. Günther, p. $1-30$. 
Gabunia, L.K., and Vekua, A.K., 1966, [Peculiar representative of hyraxes from the Upper Pliocene of East Georgia]: [Bulletin of the Academy of Sciences of the Georgian SSR], v. 42, p. 643-647. [in Georgian]

García, N., and Arsuaga, J.L., 1999, Carnivores from the early Pleistocene hominid bearing Trinchera Dolina 6 (Sierra de Atapuerca, Spain): Journal of Human Evolution, v. 37, p. 415-430.

Gervais, P., 1859, Nouvelles recherches sur les animaux vertebres dont ou trouve les ossements enfouis dans le sol de la France: Zoologie et Paléontologie Françaises, v. 8, p. 1-271.

Gray, J., 1834, Illustration of Indian Zoology, consisting of coloured plates of new or hitherto unfigured Indian animals from the collection of Major General Hardwicke: London, Treutell, Wurtz, Treutell, Richter Publishers, 2 vol., 203 p.

Hammer, Ø., 2016, PAST. PAleontologial STatistics. Version 3.14. Reference manual: Natural History Museum, University of Oslo. http://folk.uio.no/ ohammer/past/past3manual.pdf

Hammer, Ø., Harper, D.A.T., and Ryan, P.D., 2001, PAST: Paleontological statistics software package for education and data analysis: Palaeontologia Electronica, v. 4, art. 4.

Hemmer, H., Kahlke, R.-D., and Vekua, A., 2004, The Old World puma-Puma pardoides (Owen, 1846) (Carnivora: Felidae) —in the Lower Villafranchian (Upper Pliocene) of Kvabebi (East Georgia, Transcaucasia) and its evolutionary and biogeographical significance: Neues Jahrbuch für Geologie und Paläontologie, Abhandlungen, v. 233, p. 197-231.

Hemprich, F.W., and Ehrenberg, C.G., 1832, Symbolae physicae seu icones et descriptiones Mammalium quae ex itinere per Africam Borealem et Asiam occidentalem: Berlin, Ex Officina Academica, v. 2.

Hernández Pacheco, E., 1921, La llanura manchega y sus mamíferos fósiles: Comisión de Investigaciones Paleontológicas y Prehistóricas, v. 28 , p. $1-42$.

Kavanagh, K.D., Evans, A.R., and Jernvall, J., 2007, Predicting evolutionary patterns of mammalian teeth from development: Nature, v. 449, p. $427-432$

Kormos, T., 1932, Die Füchse des ungarischen Oberpliozän: Folia Zoologica et Hydrobiologica, v. 4, p. 167-188.

Koufos, G.D., 1997, The canids Eucyon and Nyctereutes from the Ruscinian of Macedonia, Greece: Paleontologia y Evolucion, v. 30/31, p. 39-48.

Koufos, G.D., 2014, The Villafranchian carnivoran guild of Greece: implications for the fauna, biochronology and paleoecology: Integrative Zoology, v. 9 , p. $444-460$

Kretzoi, M., 1943, Kochictis centenii n. g. n. sp., ein alterümlicher Creodonte aus dem Oberoligozän Sienbenbürgens: Földtany Közlöny, v. 52 , p. $190-195$.

Kurtén, B., 1968, Pleistocene Mammals of Europe: Chicago, Aldine Publishing Company, $320 \mathrm{p}$

Kurtén, B., and Crusafont Pairó, M., 1977, Villafranchian carnivores (Mammalia) from La Puebla de Valverde (Teruel, Spain): Commentationes Biologicae Societas Scientificarum Fennica, v. 85, p. 1-39.

Linnaeus, C., 1758, Systema Naturae per regna tria naturae, secundum Classes, Ordines, Genera, Species, cum characteribus, differentiis, synonymis, locis. Tomus I, $10^{\text {th }}$ edition: Stockholm, Sweden, Holmiae, Laurentius Salvius, $824 \mathrm{p}$.

Linnaeus, C., 1768, Systema naturae per regna tria naturae, secundum classes, ordines, genera, species, cum characteribus, differentiis. Tomus III, 12th edition: Stockholm, Sweden, Holmiae, Laurentii Salvii, 236 p.

Madurell-Malapeira, J., Alba, D. M., and Moyà-Solà, S., 2009, Carnivora from the late early Pleistocene of Cal Guardiola (Terrassa, Vallès-Penedès Basin, Catalonia, Spain): Journal of Paleontology, v. 83, p. 969-974.

Major, C.I.F., 1875, Considerazioni sulla Fauna dei Mammiferi pliocenici e post-pliocenici della Toscana: Atti Società Toscana Scienze Naturali, Memoire, v. 1, p. 7-40.

Major, C.J.F., 1891, On the fossil remains of species of the family Giraffidae: Proceedings of the Zoological Society of London, 1891, p. 315-326.

Martin, R., 1973, Trois nouvelles espèces de Caninae (Canidae, Carnivora) des gisements Plio-Villafranchiens d'Europe: Documents des laboratoires de géologie de la Faculté des Sciences de Lyon, v. 57, p. 87-96.

Mein, P., 1975a, Résultats du groupe de travail des vertébrés: biozonation du Néogène Méditerranéen à partir des mammifères, in Senes, J., ed., Report on Activity of RCMNS Working Groups (1971-1975): VI Congress of the Regional Committee of Mediterranean Neogene Stratigraphy, Bratislava, p. 78-81.

Mein, P., 1975b, Proposition de Biozonation du Néogène Méditerranéen à partir des mammifères: Trabajos sobre Neógeno/Cuaternario, v. 4 p. 112-113.

Merriam, J.C., 1911, Tertiary mammal beds of Virgin Valley and Thousand Creek in north-western Nevada. Part II: vertebrate faunas: University of California Publications in Geology, v. 11, p. 199-304.

Monguillon, A., Spassov, N., Argant, A., Kauhala, K., and Viranta, S., 2004, Nyctereutes vulpinus comb. et stat. nov. (Mammalia, Carnivora, Canidae) du Pliocène terminal de Saint-Vallier (Drôme, France): Géobios, v. 37, p. 83-88.

Odintzov, I.A., 1965, Vulpes praecorsac Kormos from Pliocene deposits of Odessa: Paleontologicheskyi Sbornik, L'vov University, v. 2 , p. $57-64$.

Odintzov, I.A., 1967, New species of Pliocene Carnivora, Vulpes odessana sp. nov. from the Karst Cave of Odessa: Paleontologicheskyi Sbornik, L'vov University, v. 4, p. 130-137.

Owen, R., 1846, A History of British Fossil Mammals, and Birds: London, John Van Voorst, $560 \mathrm{p}$.

Pomel, M., 1842, Nouvelle espèce de chien fossile découverte dans les alluvions volcaniques de l'Auvergne: Bulletin de la Societé géologique de France, v. 14, p. $38-41$

Popov, S.V., Shcherba, I.G., Ilyina, L.B., Nevesskaya, L.A., Paramonova, N.P., Khondkarian, S.O., and Magyar, I., 2006, Late Miocene to Pliocene palaeogeography of the Paratethys and its relationship to the Mediterranean: Palaeogeography, Palaeoclimatology, Palaeoecology, v. 238, p. 91-106.

Qiu, Z., and Tedford, R.H., 1990, A Pliocene species of Vulpes from Yushe, Shanxi: Vertebrata Palasiatica, v. 28, p. 245-258.

Qiu, Z.-X., Deng, T., and Wang, B.-Y., 2004, Early Pleistocene mammalian fauna from Longdan, Dongxiang, Gansu, China: Palaeontologia Sinica, v. 191 , p. $1-198$.

Petrucci, M., Cipullo, A., Martínez-Navarro, B., Rook, L., and Sardella, R., 2013 The late Villafranchian (Early Pleistocene) carnivores (Carnivora, Mammalia) from Pirro Nord (Italy): Palaeontographica Abteilung A, v. 298, p. $113-145$.

Rabeder, G., 1976, Die Carnivoren (Mammalia) aus dem Altpleistozän von Deutsch-Altenburg 2, mit Beiträgen zur Systematik einiger Musteliden und Caniden: Beiträge zur Paläontologie von Österreich, v. 1, p. 5-119.

Rook, L., 1992, "Canis" monticinensis sp. nov., a new Canidae (Carnivora, Mammalia) from the late Messinian of Italy: Bollettino della Società Paleontologica Italiana, v. 31, p. 151-156.

Rook, L., 2009, The wide ranging genus Eucyon Tedford \& Qiu, 1996 (Mammalia, Carnivora, Canidae, Canini) in the Mio-Pliocene of the Old World: Geodiversitas, v. 31, p. 723-741.

Schlosser, M., 1903, Die fossilen Säugethiere Chinas nebst einer Odontographie de recenten Antilopen: Abhandlungen der königlich bayerischen Akademie der Wissenschaften II. Classe, v. 22, p. 1-220.

Sillero-Zubiri, C., and Macdonald, D.W., 2004, Introduction, in Sillero-Zubiri, C., Hoffmann, M., and Macdonald, D.W., eds., Canids: Foxes, Wolves, Jackals and Dogs. Status Survey and Conservation Action Plan: Gland, Switzerland and Cambridge, UK, IUCN/SSC Canid Specialist Group, p. 2-7.

Simpson, G.G., 1941, Large Pleistocene felines of North America: American Museum Novitates, v. 1136, p. 1-27.

Simpson, G.G., Roe, A., and Lewontin, R.C., 1960, Quantitative Zoology: New York, Harcourt Brace, $440 \mathrm{p}$.

Sotnikova, M., and Rook, L., 2010, Dispersal of the Canini (Mammalia, Canidae: Caninae) across Eurasia during the late Miocene to early Pleistocene: Quaternary International, v. 212, p. 86-97.

Spassov, N., and Rook, L., 2006, Eucyon marinae sp. nov. (Mammalia Carnivora), a new canid species from the Pliocene of Mongolia, with a review of forms referable to the genus: Rivista Italiana di Paleontologia e Stratigrafia, v. 112, p. 123-133.

Tedford, R.H., and Qiu, Z., 1991, Pliocene Nyctereutes (Carnivora: Canidae) from Yushe, Shanxi, with comments on Chinese fossil raccoon-dogs: Vertebrata Palasiatica, v. 29, p. 176-189.

Tedford, R.H., and Qiu, Z.-X., 1996, A new canid genus from the Pliocene of Yushe, Shanxi Province: Vertebrata Palasiatica, v. 34, p. 27-40.

Tedford, R.H., Wang, X., and Taylor, B.E., 2009, Phylogenetic systematics of the North American fossil caninae (Carnivora: Canidae): Bulletin of American Museum of Natural History, v. 325, p. 1-218.

Teilhard de Chardin, P., and Pei, W.-C., 1941, The fossil mammals from locality 13 of Choukoutien: Palaeontologica Sinica, Series C, v. 11, p. 1-106.

Teilhard de Chardin, P., and Piveteau, J., 1930, Les mammiferes fossiles de Nihewan (Chine): Annales de Paleontologie, v. 19, p. 1-134.

Temminck, C., 1838, Over de kennis en de Verbreiding der Zoogdieren van Japan: Tijdschrift Voor Natuurlijke Geschiedenis en Physiologie, v. 5, p 273-293.

Thenius, E., 1954, Die Caniden (Mammalia) aus dem Altquartär von Hundsheim (Niederösterreich) nebst Bemerkungen zur Stammesgeschichte der Gattung Cuon: Neues Jahrbuch für Geologie und Paläontologie, Abhandlungen, v. 99 , p. $230-286$.

Vekua, A., 1968, [The Pliocene spiral-horned antelopes from Georgia]: Soobscheniya Akademii Nauk Grouzinskoi SSR, v. 3, p. 1-25. [in Russian]

Vekua, A., 1972, [Kvabebi Fauna of Akchagylian Vertebrates]: Moscow, Nauka, 258 p. [in Russian]

Viret, J., 1954, Le loess à bancs durcis de Saint-Vallier (Drôme) et sa faune de mammifères villafranchiens: Nouveau Archives du Musee d'Histoire Naturelle de Lyon, v. 4, p. 1-200. 
von den Driesch, A., 1976, A guide to the measurement of animal bones from archaeological sites: Peabody Museum Bulletin, v. 1, p. 1-137.

Wagner, A., 1848, Urweltliche Säugetierreste aus Griechenland: Abhandlungen der Bayerischen Akademie der Wissenschaften, v. 5, p. 333-338.

Wang, X., and Tedford, R.H., 2008, Dogs, and their Fossil Relatives: New York, Columbia University Press, $232 \mathrm{p}$.
Wang, X., Tseng, Z.J., Li, Q., Takeuchi, G.T., and Xie, G., 2014, From "third pole" to north pole: a Himalayan origin for the arctic fox: Proceedings of the Royal Society B, v. 281, p. 20140893. DOI: 10.1098/rspb.2014.0893.

Accepted 26 June 2017 